Yerbilimleri, 2019, 40 (2), 136-167, DOI:10.17824/yerbilimleri.519195

Hacettepe Üniversitesi Yerbilimleri Uygulama ve Araştırma Merkezi Bülteni

Bulletin of the Earth Sciences Application and Research Centre of Hacettepe University

\title{
Bakırtepe (Sivas-Kangal) altın cevherleşmelerinin oluşum ve zenginleşme evrelerinin kavramsal modeli
}

Conceptual model of formation and enrichment phases of Bakırtepe (Sivas-Kangal) gold mineralizations

\section{ÖZCAN DUMANLILAR ${ }^{1}$, ISMAIL CIHAN ${ }^{* 2}$, MEHMET EKMEKÇi ${ }^{3,4}$, GÖKHAN KANAAT ${ }^{2}$, CAN AYDOĞAN ${ }^{2}$, OĞUZ TURUNÇ ${ }^{5}$}

\footnotetext{
${ }^{1}$ Al Masane Al Kobra Mining Co. P.O. Box 46 Najran - Saudi Arabia

${ }^{2}$ Demir Export A.S. İzmir Caddesi Koç Han No: 25/7 Cankaya-Ankara, Türkiye

${ }^{3}$ Hacettepe Üniversitesi, Uluslararası Karst Su Kaynakları Araştırma Merkezi, 06800, Beytepe-Ankara, Türkiye

${ }^{4}$ Hacettepe Üniversitesi, Hidrojeoloji Mühendisliği Programı, 06800, Beytepe-Ankara, Türkiye

${ }^{5}$ Datamine, Çankaya Mah. Farabi Sokak No:7/2, 06690, Çankaya-Ankara, Turkey
}

Geliş (received): 29 Ocak (January) 2019 Kabul (accepted) : 25 Temmuz (July) 2019

\section{ÖZ}

Bakırtepe (Kangal-Sivas) altın (Au) cevherleşmeleri, Doğu Toroslar'ın kuzeydoğu kesiminde yer almakta olup Toros göreli otoktonuna ait Erken Paleozoyik-Mezozoyik yaşlı kırıntılı ve karbonatı kayaçlar içerisinde bulunmaktadır. Cevher oluşumu, dağııımı ve devamlıı̆ı ile ilgili belirsizlikler işletme ve üretim çalışmalarının etkinliğini doğrudan etkileyen konuların başında gelmektedir. Bakırtepe Au işletmesinde cevherli zonların izlenmesinde yaşanan sorunlar, birincil Au cevherleşmelerini ve ikincil zenginleşmeleri denetleyen süreçlerin aydınlatılmasını gerektirmiştir. Bu kapsamda, inceleme alanında ayrıntıı jeolojik, petrografik, jeokimyasal, XRD, sıvı kapanımı ve karstlaşma gelişimine yönelik çalışmalar gerçekleştirilerek cevherleşme ve zenginleşme aşamalarının açıklanmasına yönelik bir kavramsal model oluşturulmuştur. Oluşturulan kavramsal model, inceleme alanındaki cevherleşme ve zenginleşmenin 3 farklı evrede ele alınarak açıklanabileceğini ortaya koymuştur. Kurgulanan modelin sahaya uygulanması sonucunda üretim ve izleme ile ilgili sorunların büyük ölçüde ortadan kalktığı gözlenmiştir.

Anahtar Kelimeler: Bakırtepe, Au cevherleşmesi, jeokimya, karstlaşma, kavramsal model, sıvı kapanım, zenginleşme.

https://doi.org/10.17824/yerbilimleri.519195

$\triangle$ ismail CiHAN ismailc@demirexport.com

\footnotetext{
${ }^{1}$ Al Masane Al Kobra Mining Co. P.O. Box 46 Najran - Saudi Arabia, ORCID 0000-0003-3097-5098

${ }^{2}$ Demir Export A.Ş. İzmir Caddesi Koç Han No: 25/7 Cankaya-Ankara, Türkiye, ORCID 0000-0002-7347-1191

${ }^{3}$ Hacettepe Üniversitesi, Uluslararası Karst Su Kaynakları Araştırma Merkezi, 06800, Beytepe-Ankara, Türkiye

${ }^{4}$ Hacettepe Üniversitesi, Hidrojeoloji Mühendisliği Programı, 06800, Beytepe-Ankara, Türkiye, ORCID 0000-0002-6729-7457

${ }^{2}$ Demir Export A.S. İzmir Caddesi Koç Han No: 25/7 Çankaya-Ankara, Türkiye, ORCID 0000-0002-8826-7935

${ }^{2}$ Demir Export A.Ş. Izmir Caddesi Koç Han No: 25/7 Çankaya-Ankara, Türkiye, ORCID 0000-0003-1435-9009

${ }^{5}$ Datamine, Çankaya Mah. Farabi Sokak No:7/2, 06690, Çankaya-Ankara, Turkey, ORCID 0000-0002-4386-4330
} 


\section{ABSTRACT}

Sivas-Kangal-Bakırtepe Au mineralization is located in the northeastern part of the Eastern Taurides and occurs within the Lower Paleozoic-Mesozoic clastic and carbonate sedimentary rocks of the Taurus autochthonous units. Uncertainties associated with occurence, distribution and continuity of the ore is the primary factor that adversely affect ore production and related mining operation. Problems of locating zones enriched with $\mathrm{Au}$ required a revision of the current model and development of a new model that explains zones of primary and secondary enrichment. A comprehensive study has been conducted with the aim to develop a conceptual model. The studies included detailed geological, petrographical, geochemical, $X R D$, fluid inclusion analyses and karst processes. The conceptual model suggests that mineralization and enrichment of Au in the area can be explained by processes that took place in 3 main phases. The conceptual model was verified in practice. Mining operations were planned targetting the enriched zones as suggested by the model. The results approved to a great extent the success of the suggested model.

Keywords: Bakırtepe, Au mineralization, geochemistry, karstification, conceptual model, fluid inclusion, enrichment.

\section{GíRiş}

Cevher dağılımı ve devamlılığını ortaya koyan jeolojik modellerdeki belirsizlikler, sahada işletme ve üretim faaliyetlerinin etkinliğini denetleyen önemli faktörlerin başında gelmektedir (Annels, 1991; Sinclair and Vallée, 1998). Cevherleşme ve zenginleşme süreçlerinin tanımlanarak cevherin oluşumu, dağılımı ve devamlılığını ortaya koyacak şekilde sentezlendiği "kavramsal jeolojik model”lerin ileri düzeyde temsil ediciliği, jeolojik yapının ve cevherleşme ve zenginleşmeyi denetleyen jeolojik evrimin doğru bir şekilde kurgulanmasına bağlıdır (Stone and Dunn, 1996; Stephenson and Vann, 2001; Goldsmith, 2002, Dominy et al., 2002).

Bu çalışmaya konu olan Bakırtepe (Sivas) Au yatağında, 2006-2015 yılları arasında Demir Export A.Ş. tarafından gerçekleştirilen detay jeolojik harita alımı ve sondajlı arama 
çalışmaları sonucunda ortaya konan yaklaşımla altın üretimi yapılmaktadır (Demir Export, 2008). Bununla birlikte, sahada cevherin dağılımı ve devamlılığı ile ilgili zaman zaman üretim sorunları yaşanması ilk aşamada önerilen “kavramsal jeolojik modeli”n gözden geçirilmesini gerektirmiştir.

Bu kapsamda, Demir Export A.Ş.'ye ait verilerin bir kısmı kullanılarak Bakırtepe Au cevherleşmelerinin jeolojik, mineralojik ve jeokimyasal özellikleri incelenerek amaç doğrultusunda değerlendirilmiş ve farklı tipteki cevherleşmeler tanımlanmıştır. Önceki çalışmalarda değinilmeyen ancak sahada gözlenen karstlaşma, ikincil zenginleşmenin bağlantılı olabileceği diğer bir süreç olma potansiyeli nedeniyle ayrıca çalışılmıştır.

Yukarıda tanımlanan çalışmalar sonucunda, Bakırtepe altın işletmesinde karşılaşılan üretim sorunlarını çözmek üzere birincil cevherleşme ve ikincil zenginleşme süreçlerine dayalı bir "kavramsal jeolojik model" oluşturulmuştur. Sahada sınanan modelin işletme ve üretim açısından olumsuzluklara neden olan "izlenebilirlik" sorununu büyük ölçüde çözdüğü anlaşılmıştır.

Çalışma alanı Sivas ili, Kangal ilçe sınırları içerisinde, $39^{\circ} 15^{\prime} 2^{\prime \prime}$ N enlem ile $37^{\circ} 35^{\prime} 17^{\prime \prime} \mathrm{E}$ boylamında ve Türkiye 1/25.000 ölçekli J39 d2 paftasında yer almaktadır (Şekil 1).

Bölgedeki Au aramalarına yönelik ilk çalışma 1992 yılında MTA Genel Müdürlüğü tarafından yapılmıştır. Bu çalışmalar sonucunda, Bakırtepe civarındaki kuvarsitler içindeki kuvars damar ve damarcıklarının Au içerdiği belirlenmiştir (Tekin vd., 1993).

Bu çalışmaları, bölgedeki cevherleşmenin kökenine ilişkin çalışmalar izlemiştir. Koçak ve Avcı (2003) cevherleşmenin hidrotermal kökenli olduğunu ve sahanın kuzey ve güney yamaçlarında faylarla ilişkili olmak üzere farklı iki Au cevherleşmesinin oluştuğunu ileri sürmüşlerdir.

Uçurum vd. (2007) ise sıvı kapanım ve izotop çalışmalarına dayanarak Bakırtepe'deki Au oluşumlarının Fe oksitlere bağlı olarak gelişmiş damar tipi cevherleşmeler olduğunu belirtmişlerdir. 


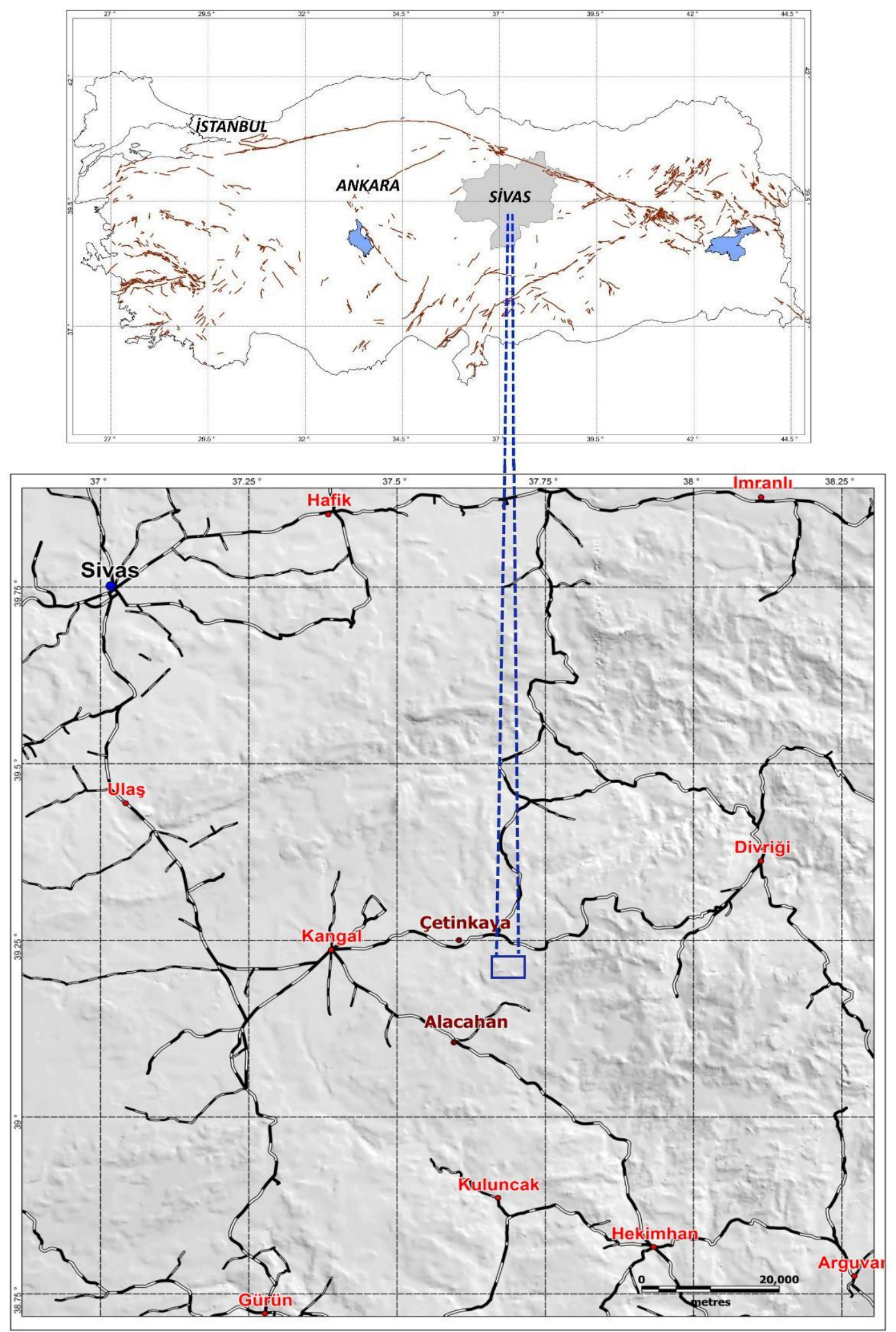

Şekil 1. İnceleme alanın yer bulduru haritası.

Figure 1. Location map of the study area. 


\section{MATERYAL VE YÖNTEM}

Bu çalışmada tanımlanan amaç doğrultusunda, yoğun bir arazi, sondaj, analiz ve değerlendirme çalışmaları yürütülmüştür. Arazi çalışmaları başlıca Bakırtepe $A u$ cevherleşmelerini içeren bölgenin 1/5.000 ölçekli jeoloji haritasının hazırlanması ve karstik yapıların tanımlanarak haritalanmasını kapsamıştır. Alterasyon ve cevher mineralojisine yönelik olarak karotlardan seçilen 87 adet örnekte parlatma/ince kesit ile 18 adet örnekte XRD çalışması yapılarak mineralojik bileşim incelenmiştir. Ayrıca altere zona ait 1148 adet karot örneğinden yapılan jeokimyasal analizler kullanılarak alterasyon zonlarının jeokimyasal özellikleri incelenmiştir. ALS Chemex İzmir Laboratuvarı'na gönderilen karot numuneleri, WEI-21 (alınan örneklerin tartılması), LOG-22 (örneklerin takip sistemine kaydedilip, barkot etiketi yapıştırılması), CRU-31 (örneklerin \%70'i 2 mm'nin altına inecek şekilde ince kırmaya tabi tutulması), SPL-21 (splitter ile örneklerin ayrılması) ve PUL-31 (ayrılan örneklerin 250 g'ık kısmının, \%85’ 75 mikronun altına inecek şekilde öğütülmesi) aşamalarından geçerek analize hazır hale getirilmiştir. Analize hazır hale gelen örnekler, ALS Chemex İzmir laboratuvarlarında altın analizi için Au-AA24 (ateşte deney füzyonu ve atomik absorpsiyon spektrometresi), multi-element analizi için ME-MS61 (İndüktif Eşleşmiş Plazma Kütle Spektrometresi ve İndüktif Eşleşmiş Plazma Atomik Emisyon Spektrometrisi) analizlerine tabi tutulmuştur. Altın içeriğinin 10 ppm'den yüksek olması durumunda, bu numuneler ALS Chemex tarafından Au-GRA22 (ateşte deney füzyonu ve gravimetrik) analizlerine tabi tutulmuştur. Analiz metotlarının alt ve üst limitleri Çizelge 1'de verilmiştir.

Çizelge 1. Karot örneklerine uygulanan analiz metotlarının alt ve üst limitleri.

Table 1. Upper and lower detection limits of the analysis methods applied to core samples.

\begin{tabular}{|c|c|c|c|c|c|c|c|c|c|c|c|}
\hline \multirow[b]{2}{*}{ Element } & \multirow[b]{2}{*}{ Aralık } & \multicolumn{4}{|c|}{ ME-MS61 analiz metodu alt ve üst limitleri } & \multirow[b]{2}{*}{ Element } & \multirow[b]{2}{*}{ Aralık } & \multicolumn{2}{|c|}{$\begin{array}{l}\text { Au-AA24 analiz } \\
\text { metodu alt ve üst } \\
\text { limitleri }\end{array}$} & \multicolumn{2}{|c|}{$\begin{array}{l}\text { Au-GRA22 analiz } \\
\text { metodu alt ve üst limitler }\end{array}$} \\
\hline & & Element & Aralık & Element & Aralık & & & Element & Aralık & Element & Aralık \\
\hline $\mathrm{Ag}(\mathrm{ppm})$ & $0,01-100$ & $\mathrm{Cu}(\mathrm{ppm})$ & $0,2-10.000$ & $\mathrm{Na}(\%)$ & $0,01-10$ & $\mathrm{Sr}(\mathrm{ppm})$ & $0,2-10.000$ & $\mathrm{Au}(\mathrm{ppm})$ & 0,005-10 & $\mathrm{Au}(\mathrm{ppm})$ & $0,05-1.000$ \\
\hline $\mathrm{Al}(\%)$ & $0,01-50$ & $\mathrm{Fe}(\%)$ & $0,01-50$ & $\mathrm{Nb}(\mathrm{ppm})$ & $0,1-500$ & Ta (ppm) & $0,05-100$ & & & & \\
\hline As (ppm) & $0,2-10.000$ & $\mathrm{Ga}(\mathrm{ppm})$ & $0,05-10.000$ & $\mathrm{Ni}(\mathrm{ppm})$ & $0,2-10.000$ & Te (ppm) & $0,05-500$ & & & & \\
\hline $\mathrm{Ba}(\mathrm{ppm})$ & $10-10.000$ & $\mathrm{Ge}(\mathrm{ppm})$ & $0,05-500$ & $\mathrm{P}(\mathrm{ppm})$ & $10-10.000$ & Th (ppm) & $0,01-10.000$ & & & & \\
\hline $\mathrm{Be}(\mathrm{ppm})$ & $0,05-1.000$ & $\mathrm{Hf}(\mathrm{ppm})$ & $0,1-500$ & $\mathrm{~Pb}(\mathrm{ppm})$ & $0,5-10.000$ & $\mathrm{Ti}(\%)$ & $0,005-10$ & & & & \\
\hline $\mathrm{Bi}(\mathrm{ppm})$ & $0,01-10.000$ & In (ppm) & $0,005-500$ & $\mathrm{Rb}(\mathrm{ppm})$ & $0,1-10.000$ & TI (ppm) & $0,02-10.000$ & & & & \\
\hline $\mathrm{Ca}(\%)$ & $0,01-50$ & $\mathrm{~K}(\%)$ & $0,01-10$ & $\operatorname{Re}(p p m)$ & $0,002-50$ & $\mathrm{U}(\mathrm{ppm})$ & $0,1-10.000$ & & & & \\
\hline $\mathrm{Cd}(\mathrm{ppm})$ & $0,02-1.000$ & La (ppm) & $0,5-10.000$ & $\mathrm{~S}(\%)$ & $0,01-10$ & $\mathrm{~V}(\mathrm{ppm})$ & $1-10.000$ & & & & \\
\hline $\mathrm{Ce}(\mathrm{ppm})$ & $0,01-500$ & $\mathrm{Li}(\mathrm{ppm})$ & $0,2-10.000$ & $\mathrm{Sb}(\mathrm{ppm})$ & $0,05-10.000$ & W (ppm) & $0,1-10.000$ & & & & \\
\hline Co (ppm) & $0,1-10.000$ & $\mathrm{Mg}(\%)$ & $0,01-50$ & $\mathrm{Sc}(\mathrm{ppm})$ & $0,1-10.000$ & $\mathrm{Y}(\mathrm{ppm})$ & $0,1-500$ & & & & \\
\hline $\mathrm{Cr}(\mathrm{ppm})$ & $1-10.000$ & $\mathrm{Mn}(\mathrm{ppm})$ & $5-100.000$ & $\mathrm{Se}(\mathrm{ppm})$ & $1-1.000$ & $\mathrm{Zn}(\mathrm{ppm})$ & $2-10.000$ & & & & \\
\hline Cs (ppm) & $0,05-500$ & Mo (ppm) & $0,05-10.000$ & Sn (ppm) & $0,2-500$ & $\mathrm{Zr}(\mathrm{ppm})$ & $0,5-500$ & & & & \\
\hline
\end{tabular}


Çalışma alanı ve yakın dolayındaki jeolojik yapının cevherleşme açısından incelenmesine ek olarak, cevherleşme ve zenginleşme evrelerinde rol oynayabilen karstlaşma olgusunun da ayrıntılı bir şekilde irdelenmesi gerekmiştir. Bu doğrultuda, bölgesel karstlaşma evriminin ortaya konmasına yönelik değerlendirmelerin yanı sıra, ocak içi çalışmalarda karstik yapıların haritalanmasına özel bir önem verilmiştir.

Gözlem, analiz ve değerlendirmeler, işletme sırasında karşılaşılan "izleme" sorunlarının çözümüne yönelik olarak özellikle zenginleşme ile ilgili bir kavramsal modelin oluşturulması gerektiğini ortaya koymuştur. Modelleme çalışmasında, inceleme alanının bölgesel ve yerel jeolojisi, karst olgusu ve karstlaşma süreçleri, mineralojik bileşim, alterasyon, sıvı kapanım ve jeokimyasal analizlerden yararlanılmıştır.

Çalışmada kullanılan örnek ve analiz sonuçları aşağıda ilgili bölümlerde ayrıntılı olarak verilmiştir.

\section{ÇALIŞMA ALANININ JEOLOJISi}

\section{Bölgesel Jeoloji}

Çalışma alanının da içinde bulunduğu Kangal-Divriği arasındaki bölgeyi kapsayan Doğu Toroslar'ın kuzeydoğu kesiminin genel jeolojisine yönelik çalışmalar Gültekin (1993); Yalçın ve Bozkaya (1997); Yılmaz ve Yılmaz (2004) ile Beyazpirinç ve Akçay (2013) tarafından yapılmıştır.

Bölgeye özgü temel kayalar, Erken Paleozoyik-Mesozoyik yaşlı Toros Göreli Otoktonuna ait birimler ile Jura yaşlı ofiyolitler ve Geç Kretase yaşlı ofiyolitik karışık ile temsil edilmektedir. Toros Göreli Otoktonunun en alt düzeyi metakırıntılı Devoniyen-Erken Karbonifer yaşlı Kangal Formasyonu ile temsil edilir. Bu formasyonu üste doğru uyumlu olarak Erken Karbonifer-Kampaniyen yaşlı rekristalize Munzur Kireçtaşı izler (Yılmaz ve Yılmaz, 2004). İnceleme alanında ise Kangal Formasyonu ile Munzur Kireçtaşları tektonik olarak izlenmektedir (Şekil 2). Munzur Kireçtaşı üzerinde tektonik dokanakla yer alan Geç Kretase yerleşim yaşlı Güneş Ofiyoliti, inceleme alanının kuzeyinde silisleşmiş serpantinitler ile temsil edilmektedir (Bayhan, 1980), (Şekil 2). Toros Göreli Otoktonu ve Güneş Ofiyolitinden oluşan mozayiğin üzerine uyumsuz olarak Maastrihtiyen yaşlı Saya Formasyonu gelmektedir. Volkano-tortul bir istif olan Saya Formasyonu, Gültekin (1993) tarafından tanımlanmış olup inceleme alanının kuzeydoğusunda Güneş Ofîyoliti'nin üzerine uyumsuz olarak gelmektedir. Volkano-tortul istif, alttan üste doğru çakıltaşı- 
kumtaşı-çamurtaşı-marn ardalanması, kireçtaşı mercekleri, aglomera, tüf ve yer yer spilitik lavlardan oluşmaktadır.

Paleosen yaşlı granitoyidler, temeli oluşturan tektonik birimler ile Maastrihtiyen yaşlı volkano-tortul istifi intruzif olarak kesmiştir (Yılmaz ve Yılmaz, 2004; Beyazpirinç ve Akçay, 2013). Boztuğ vd. (1997) tarafından Paleotektonik dönem birimlerini kesen bu granitoyidlerin çarpışma sonrası bir evreye ait olduğu kabul edilmektedir.

Temel birimler ve Maastrihtiyen yaşlı Saya Fomasyonu, Maastrihtiyen-Kuvaterner aralığında gelişmiş sedimanter-volkanik birimler tarafından örtülmektedir.

\section{Yerel Jeoloji}

Bakırtepe altın cevherleşmelerinin bulunduğu bölgenin temelinde Kangal Formasyonuna ait birimler yüzeylemektedir. Kuzeyde Kangal Formasyonunun üzerine tektonik olarak yerleşmiş Munzur Kireçtaşları, bunların üzerinde ise ofiyolitlere ait altere serpantinitler yer almaktadır (Şekil 2). Pınargözü (Çetinkaya) Fe yatağında, doğrultuları $\mathrm{K} 60^{\circ} \mathrm{D}$ ile DB arasında değişen kırık hatları boyunca Munzur Kireçtaşları ile ofiyolitleri ve bu iki birim arasındaki tektonik düzlemi keser konumda mağmatik kayaçlar izlenmektedir. Yatak çevresindeki bu birimler, kuvars diyorit porfir ve andezit olarak adlandırılmıştır (Karakaya, 2011).

Bakırtepe Au mineralizasyonunun izlendiği bölgede gözlenen birimler aşağıda tanımlanmıştır.

\section{Kangal Formasyonu}

İnceleme alanında gözlenen en yaşlı birim, Devoniyen- Erken Karbonifer yaşlı Kangal Formasyonu olup yeşilşist fasiyesinde metamorfizma geçirmiş kayaçlardan oluşmaktadır (Gültekin, 1993). Birim, Yılmaz ve Yılmaz (2004) tarafından Kınalar, Düzce ve Bakırtepe üyeleri olarak ayırt edilmiştir.

\section{Kınalar Üyesi}

Devoniyen- Erken Karbonifer yaşlı (Sayar ve Gültekin, 1993) Kınalar Üyesi, Kangal Formasyonunun tabanında görülen metapelitik kayaçlar arduvaz, klorit-mika şist, metakumtaşı, metaçamurtaşı ve siyah rekristalize kireçtaşından oluşmaktadır (Yılmaz ve Yılmaz, 2004; Yalçın ve Bozkaya, 1997). 

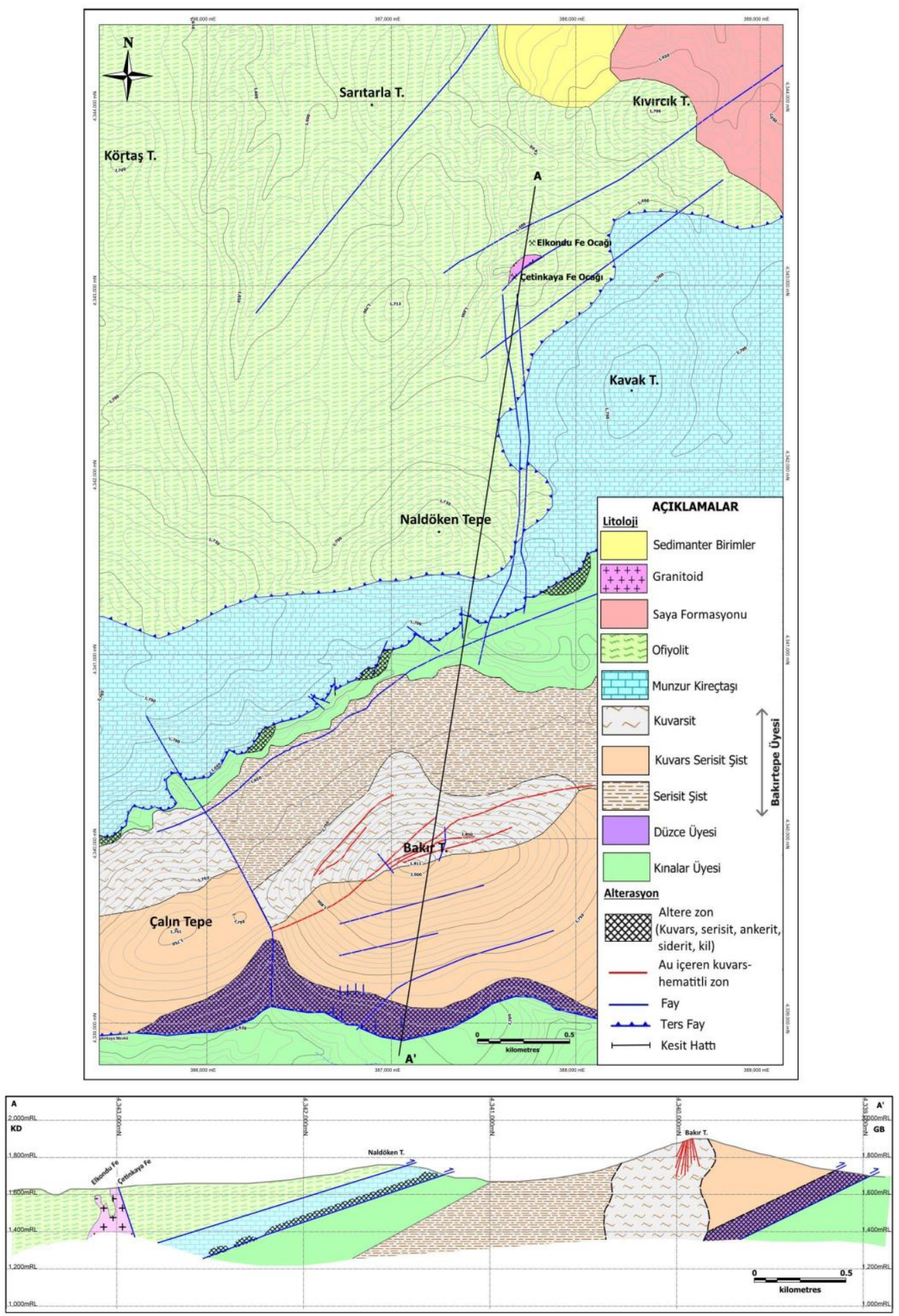

Şekil 2. İnceleme alanı ve yakın çevresinin jeoloji haritası ve kesiti.

Figure 2. Geological map and section of the study area and its vicinity.

Çalışma alanında, Bakırtepenin kuzey ve güneyinde yüzeylenen birim, tabanda arduvaz, üst seviyelerinde ise arduvaz ve metaçamurtaşından oluşmaktadır (Şekil 2). Kuzey bölümde arduvazlar arasında klorit-muskovit şist bantları bulunmaktadır. Tabanda yer alan arduvaz, siyahımsı-koyu yeşil renkli, kırılgan, düzgün laminalı ve ince taneli bir yapı 
göstermektedir. Mikroskop incelemelerinde yönlü doku gösteren kayaç, kuvars, serizit, organik materyal (kömürümsü malzeme) ve karbonat minerallerinden oluşmaktadır.

Metaçamurtaşı ile ardalanmalı olarak izlenen arduvaz sondajlarda koyu yeşilimsi ve gri renklerde olup mostrada ise grimsi kahverenkli görülmektedir. Kuvars, serizit ve karbonat mineralleri içermektedir. Tabanda yer alan arduvazdan farklı olarak iyi yönlenme sunmamakta ve organik materyal içermemektedir. Metaçamurtaşı, ince taneli kuvars mineralleri ile yönlenme gösteren serizit ve yer yer muskovitten oluşmuştur. Kırık ve çatlaklarında, karbonat, kuvars ve Fe-oksit minerallerini içeren damarlar bulunmaktadır.

\section{Düzce Üyesi}

Kınalar Üyesi ile yanal ve düşey yönde tedrici geçişli gözlenen Düzce Üyesi, krem, bej renkli, orta-kalın katmanlı rekristalize kireçtaşı ve metaçamurtaşı ardalanmasından oluşmuştur (Gültekin, 1993; Yalçın ve Bozkaya, 1997; Yılmaz ve Yılmaz, 2004). Bu ardalanma içerisindeki kireçtaşları yoğun alterasyona uğramıştır. Alterasyon şiddeti ve mineral içeriğine göre kireçtaşları kahverengi ve sarı renklerde izlenmektedir. Kireçtaşlarının kalınlığı sondaj verilerine göre $0.20 \mathrm{~m}$ ile $32.50 \mathrm{~m}$ arasında değişmektedir. Sayar ve Gültekin (1993) tarafından yapılan çalışmada, birimde Devoniyen- Erken Karbonifer yaşını veren fosiller bulunmuştur.

Mikroskop incelemelerinde rekristalize kireçtaşının mozaik doku gösterdiği, ince taneli kalsit ile çok az miktarda kuvars ve muskovitten oluştuğu belirlenmiştir. Düzce Üyesi içerisindeki metaçamurtaşları Kınalar Üyesi içerisinde yer alan metaçamurtaşları ile benzer özellik sunmaktadır.

Bölgede stratiğrafik olarak Kınalar Üyesi ile yanal ve düşey yönde geçişli olan Düzce Üyesi (Gültekin, 1993) çalışma alanında, Kınalar Üyesi üzerine tektonik olarak gelmektedir.

\section{Bakırtepe Üyesi}

Düzce Üyesi üzerinde uyumlu olarak yer alan kuvarsit ve metaçamurtaşı-metasilttaşları, Gültekin (1993) tarafından Bakırtepe Metakuvarsit Üyesi olarak tanımlanmıştır. Yalçın ve Bozkaya (1997) tarafından ise Bakırtepe Üyesi olarak tanımlanan düşük dereceli metamorfizma gözlenen birimin, gri-beyaz renkli kuvarsit, gri-siyah renkli kuvars-serizit şist, gri-beyaz renkli serizit şist ve yeşil renkli metasilttaşından oluştuğu belirtilmektedir. 
Düzce Üyesi üzerine uyumlu olarak gelmesi göz önüne alınarak stratigrafik konumuna göre ve Toroslardaki benzer fasiyeslerle korelasyonu yapıldığında birimin Erken Karbonifer yaşlı olduğu kabul edilebilir. Genel olarak kuvarsitlerden oluşan Bakırtepe Üyesinin köken kayasının kuvarsca zengin kumtaşı olduğu, bu gözleme dayanılarak birimin kıyı-plaj ortamında çökeldiği söylenebilir (Beyazpirinç ve Akçay, 2013).

Çalışma alanında jeolojik birimler, Bakırtepenin doruk noktası dolayında kuvarsit ve kuvars-serizit şist, Bakırtepe kuzey yamacı ile Çalın dere arasında ise serizit şist ile temsil edilmektedir.

Kuvarsit ve kuvars-serizit şist, pembe, gri ve beyaz renkli olup sert ve keskin yüzeyli, bol kırıklı, çatlaklı ve tabakalı bir yapıya sahiptir. Tabaka konumu $\mathrm{K} 40^{\circ}-80^{\circ} \mathrm{D} / 25^{\circ}-50^{\circ} \mathrm{KB}$ arasında değişmekte olup, hakim olarak $\mathrm{K} 60^{\circ} \mathrm{D} / 40^{\circ} \mathrm{KB}$ 'dır. Yapılan mineralojik incelemelerde, birimin başlıca kuvars, serizit, plajiyoklas, K-feldispat ve opak mineralleri içerdiği gözlenmiştir. Ayrıca birim içerisinde Fe-oksit minerallerinin bulunduğu kesimler, sahada koyu kırmızımsı ve kahverengi renklerle tipiktir. Birim ince-orta-kalın katmanlıdır. Yüzeyde ve sondaj karotlarında, kuvarsit ve kuvars-serizit şistlerin, ara seviyelerinde maksimum 1 m kalınlıkta metasilttaşları yer almaktadır.

Bakırtepenin kuzey yamacı ile Çalın dere arasında yüzeylenen serizit şist, laminasyon göstermekte olup gri-beyaz ve yer yer sarı-kahve renklidir. Laminasyon düzlemleri ile kırık ve çatlarda limonitleşme izlenmektedir. Serizit şist içerisinde kalınlıkları $0.25 \mathrm{~m}$ ile $2.50 \mathrm{~m}$ arasında değişen kuvarsit ara tabakaları bulunmaktadır. Yapılan mineralojik incelemelerde, serizit, kil mineralleri, muskovit ile çok az miktarda kuvars belirlenmiştir.

\section{Munzur Kireçtaș}

Doğu Anadolu'da tanımlandığı yer olan Munzur dağlarında, alttan üste doğru algli kireçtaşı, oolitik kireçtaşı, algli ve foraminiferli kireçtaşı, neritik kireçtaşı, çörtlü kireçtaşı, rudistli biyostromal kireçtaşı ve pelajik kireçtaşlarından oluşan birim Erken TriyasKampaniyen yaşındadır (Özgül, 1976; Özgül vd., 1981). Bununla beraber, inceleme alanı KD'sunda Naldöken tepe mevkiinde yapılan paleontolojik çalışmalar sonucunda birimin yaşının Erken Karbonifer'e kadar indiği belirlenmiştir (Yılmaz ve Yılmaz, 2004). Munzur Kireçtaşları, inceleme alanının kuzeyinde Kınalar Üyesi üzerine tektonik olarak gelmektedir (Şekil 2). 


\section{YAPISAL JEOLOJi}

Sivas-Divriği arasında, özellikle ofiyolitlerin ilksel konumlarından günümüzdeki yerlerine gelip yerleşmelerine kadar geçen süreci yansıtan unsurlar paleotektonik dönem yapıları, Maastrihtiyen-Alt Pliyosen aralığında oluşan yapısal unsurlar geçiş dönemi tektonik yapıları ve Üst Pliyosen-Kuvaterner aralığında oluşmuş, doğrultu atımlı rejimin egemen olduğu yapısal unsurlar ise neotektonik dönem yapıları olarak ayırt edilmiştir (Yılmaz ve Yılmaz, 2004).

Maastrihtiyen öncesi yaşta olan paleotektonik yapılar, ağırlıklı olarak kuzeye eğimli bindirmelerle temsil edilmektedirler. Bu yapılar boyunca allokton birimler, göreli otoktonun üzerinde yer almaktadır. Geç Pliyosen-Kuvaterner yaşlı neotektonik yapılar ise atımları 1 km'yi geçmeyen KD-GB ve KB-GD doğrultulu eşlenik faylar ve K-G doğrultulu normal faylarla temsil edilmektedir (Yılmaz ve Yılmaz, 2004).

İnceleme alanının kuzey ve güneyinde paleotektonik döneme ait yapılar izlenmektedir. Kuzeyde, alttan üste (güneyden-kuzeye) doğru tektonik dokanakla, Kınalar Üyesi, Munzur Kireçtaşları ve Güneş Ofiyoliti yer almaktadır. Özellikle Kınalar Üyesi ile Munzur Kireçtaşları arasındaki tektonik hatlar boyunca alterasyon ve altın mineralizasyonları izlenmektedir. $\mathrm{Bu}$ birimler arasındaki tektonik dokanaklar bindirme fayı olup $\mathrm{K} 70^{\circ} \mathrm{D}$ konumludur. Kınalar Formasyonuna ait birimlerdeki şist yönelimleri $\mathrm{K} 30^{\circ}-70^{\circ} \mathrm{D} / 25^{\circ}-60^{\circ} \mathrm{KB}$ ile D-B $/ 60^{\circ} \mathrm{K}$ arasında değişmektedir. Bakırtepe Üyesi içerisindeki tabakalanma konumları ise ana paleotektonik yapılarla uyumlu olarak gelişmiş olup $\mathrm{K} 40^{\circ}-80^{\circ} \mathrm{D} / 25^{\circ}-50^{\circ} \mathrm{KB}$ arasında değişmekte, hakim olarak ise $\mathrm{K} 60^{\circ} \mathrm{D} / 40^{\circ} \mathrm{KB}$ 'dır. Bu kırık hatları, Au içeren kuvars ve hematitli damar ve damarcıkları tarafından doldurulmuştur. İnceleme alanının güneyinde ise Kınalar Üyesi ile Düzce Üyesi arasındaki dokanak bindirme fayı olup yaklaşık D-B doğrultulu ve K'ye eğimlidir. Düzce Üyesi içerisinde de benzer özellikte faylar bulunmaktadır. Bu tektonik hatlar yoğun alterasyona uğramış olup işletilen Bakırtepe Au yatağı bu zonlar içerisinde yer almaktadır.

Ayrıca inceleme alanında gelişmiş çok sayıda K-G doğrultulu, üstte anlatılan bindirmeleri kesen faylar bulunmakta olup doğrultu boyunca devamlılıkları 500 m civarındadır. Verev yönde küçük atımlara (yaklaşık 50 m civarında) neden olan bu faylar, saha ilişkileri değerlendirildiğinde neotektonik döneme ait yapısal unsurlar olarak değerlendirilebilir. 


\section{KARSTLAŞMA}

Düzce üyesinin orta-kalın katmanlı rekristalize kireçtaşlarında, karstlaşma etkisi görülen yüzey morfolojisinin yanı sıra işletme yapılan açık ocak kazı yüzeylerinde, yerel ölçeklerde karstlaşmaya bağlı olarak gelişmiş çözünme/çökelme yapıları gözlenmiştir. Ocak içinde karst yapılarına yönelik olarak gerçekleştirilen inceleme ve haritalama çalışmaları, karstlaşmanın Bakırtepe Au yatağında, cevherleşme ve özellikle zenginleşme süreçlerinde önemli bir rol oynamış olabileceğini göstermiştir. Bu gözlem sonucunda alanda karstlaşma süreçleri ve karstlaşma evrimine yönelik daha ayrıntılı bir çalışma yapılarak, karstlaşma ile cevherleşme-zenginleşme ilişkisinin ortaya konması amaçlanmıştır.

Türkiye'de, Toroslarda karstlaşma süreçleri ile ilgili cevherleşmeler $(\mathrm{Pb}-\mathrm{Zn})$ yaygın olarak Yahyalı-Zamantı bölgesinde bulunur. Ayrıca Malatya-Yeşilyurt civarındaki altınlı florit oluşumunun Revan ve diğ. (2003) ile Revan ve Genç (2003) tarafından yapılan çalışmada karstlaşma süreçleri ile ilintili olduğu vurgulanmaktadır. Bu çalışma ile Divriği-Kangal arasında cevherleşme-karst ilişkisi ilk defa irdelenmiştir.

Bakırtepe Au yatağında, Ekmekçi (2003) tarafından, Geç Miyosen ve Pliyosende bölgedeki yükselimlere bağlı olarak gelişen tektonizmanın ürünü olan karstlaşmanın etkin bir şekilde devam ettiği ve yer altı drenajının çok iyi bir şekilde geliştiği ifade edilmektedir. İnceleme alanındaki, benzer ürünler olan en genç tektonizmaya ait K-G yönlü faylar, Düzce Üyesine ait altere ve mineralize olmuş rekristalize kireçtaşları içerisinde karstlaşmaların gelişimine yardımcı olmuştur.

Çalışma alanında güncel karstlaşmaya ilişkin yapılar yerel ölçekte olup yaygın değildir. Çalışma alanının morfolojisi, genel olarak iki temel süreç sonucunda şekillenmiştir. Kızılırmak vadisinin gelişimine bağlı olarak evrimleşen aşınım düzeyleriyle ilişkili olarak yüzey topoğrafyası şekillenirken, karbonatlı birimlerde etkili olan çözünme süreçleri yüzey ve yeraltı karstik yapılarının gelişmesini sağlamıştır. Çalışma alanında karstlaşma, Munzur Kireçtaşları ile Düzce Üyesinin rekristalize kireçtaşı seviyelerinde etkili olmuştur. Bununla birlikte, bu iki farklı birimde gözlenen karstlaşma süreçleri sonucunda oluşan karstik yapılar biribirlerinden önemli farklılıklar sunarlar. Munzur Kireçtaşları, meteorik suların çözücü etkisiyle, yüzeyden derinlere doğru karstlaşmış, bunun sonucunda yeraltı karst boşlukları ile birlikte düden ve dolin gibi yüzey karst yapıları oluşturmuştur. Düzce Üyesinde ise karstlaşma öncelikle, rekristalize kireçtaşları ile sınırlı kalmış ve kireçtaşlarını sınırlayan metaçamurtaşlarında etkisini göstermemiştir. Bu nedenle, Düzce Üyesinde karstlaşma, kireçtaşı seviyelerinin kalınlığına bağlı olarak 0.5-10 m boyutlarında gözlenmektedir. 
Bununla birlikte karstlaşma, kireçtaşı seviyelerinin uzanımı boyunca devamlı bir şekilde gelişim göstermiştir.

Munzur kireçtaşlarında ve Düzce üyesine ait rekristalize kireçtaşının yüzeylendiği alanlarda yüzeyde dar çaplı çözünme yapıları gözlenmektedir (Şekil 3). Karstlaşmaya uygun kireçtaşlarının dar alanlarda yayılım göstermesi ve ardalanma gösterdiği karstlaşamayan çamurtaşları ile sınırlandırılması, karstlaşmanın ileri düzeyde gelişmesini engellemiştir. Çalışma alanı ve yakın dolayında, dolin, uvala, polye, mağara gibi karstlaşmanın ileri düzeylerinin göstergesi olan yapılara bu nedenle rastlanılmamaktadır. Bununla birlikte, ocak içinde, dar alanlarda ve küçük ölçeklerde de olsa karstlaşma sonucu oluşan karst boşluklarına sık rastlanmıştır (Şekil 4a). Karst boşluklarının genellikle Fe-oksit içeriği yüksek, terra rosa olarak nitelendirilen ince taneli malzeme ile kısmen veya tamamen doldurulmuş olduğu gözlenmiştir (Şekil 4b). Büyük ölçüde kireçtaşındaki çözünmeyen (silikat) minerallerinden oluşan ve karstlaşma sonucu biriken kızıl-kızıl kahverenkli bu ince malzemenin yüzeye yakın kesimlerde tutturulmamış, daha derin kesimlerde ise daha sıkılaşmış olduğu gözlenmiştir (Şekil 4c).

Cevherin yayılım ve dağılımına yönelik haritalama çalışmaları sırasında boşluk, dolgu türü, dolgu oranı gibi karstlaşma süreçleriyle bağlantılı yapılar da haritalanmıştır. Haritalama sonucunda, cevherce zengin malzemenin konumu ile karstik yapı türü ve dağılımı arasında belirli bir ilişkinin olabileceği belirlenmiştir. Ortamın jeolojisi, maden jeolojisi, mineralojik analizler ve tenör verileri ile birlikte değerlendirildiğinde, özellikle Au zenginleşmesinin karstlaşma süreçleri ile bağlantılı olduğunu ortaya koymuştur. Karst morfolojisi, mineralojik, XRD ve jeokimyasal analizler, karstlaşma evriminin bölgede iki aşamalı olarak geliştiğini göstermiştir. Karstlaşmaya bağlı olarak gelişen minerallerde yapılan sıvı kapanım analizleri, jeolojik tarihçe içinde bölgede iki farklı karstlaşma sürecinin gerçekleştiği kurgusunu desteklemiştir: derinlerden yukarıya doğru hidrotermal akışkanla gelişen "hipojenik karstlaşma" ve yukarıdan derinlere doğru gelişen ve yağış sularının etkisiyle gelişen "meteorik (normal) karstlaşma". Aşağıdaki bölümlerde iki aşamalı karstlaşma süreçleri ve bu süreçlerin cevher zenginleşme süreçleri ile olan ilişkileri ayrıntılı olarak verilmiştir. 


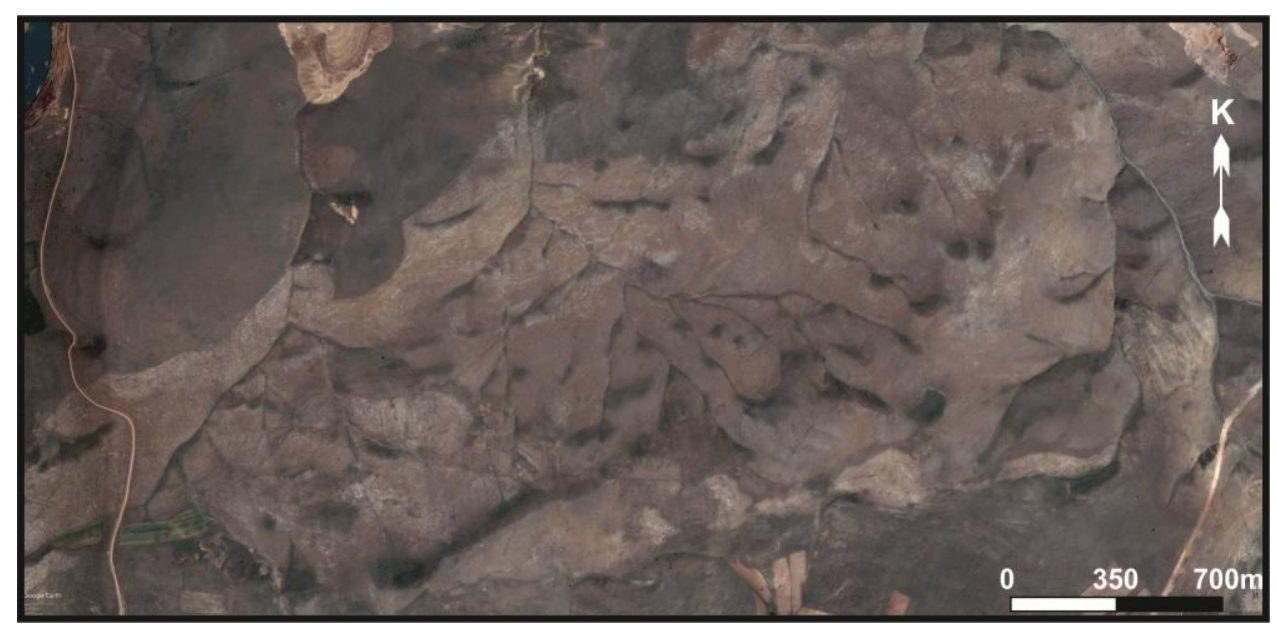

Şekil 3. Çalışma alanı ve yakın dolayında gözlenen karst yapılarına ait GoogleEarth (2019) görüntüsü.

Figure 3. GoogleEarth (2019) image of the karstic features in the study area and its vicinity.

\section{MADEN JEOLOJISI}

Çalışma alanındaki Au cevherleşmeleri (a) kuzeyde Naldöken tepe civarında Munzur Kireçtaşları ile Kınalar Üyesine ait metamorfikler arasındaki tektonik hatlarda, (b) Bakırtepe'nin kuzey yamacında Bakırtepe Üyesi içerisindeki (kuvarsit) kırık hatlarında ve (c) Bakırtepe'nin güney yamacında Düzce Üyesine ait kireçtaşlarının içerisinde olmak üzere üç lokasyonda izlenmektedir (Şekil 2).

Naldöken tepe Au cevherleşmesi: Kınalar Üyesine ait metamorfikler ile Munzur Kireçtaşları arasındaki tektonik hatta izlenmektedir (Şekil 2). İnceleme alanında, yaklaşık $\mathrm{K} 70^{\circ} \mathrm{D}$ uzanımlı olarak $3.2 \mathrm{~km}$ izlenmekte olan tektonik hattın kalınlığı yer yer 80 m'ye kadar çıkmaktadır. Tektonik hat boyunca silisleşme, killeşme, yer yer hematitli, breşik ve ezik zonlar gözlenmektedir. Limonit ve hematitler saçınımlı, damar ve damarcıklar şeklinde izlenmektedir. 


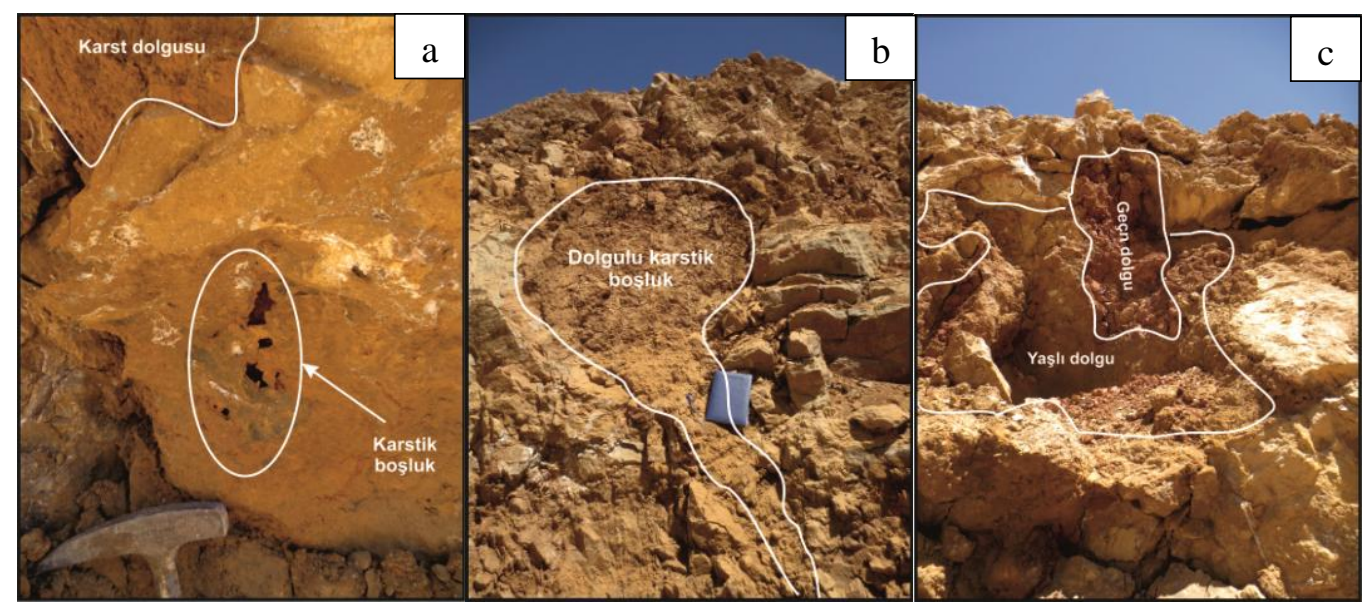

Şekil 4. a) Ocak içinde küçük ölçeklerde rastlanan karst boşlukları, b) dolgulu karst boşluğu c) farklı dönemlere ait malzeme ile doldurulmuş karst boşluğu.

Figure 4. a) Karstic cavities located in the mine pit, b) karstic cavity filled with fine material, c) karstic cavity filled with material in different phases.

Bakırtepe kuzey sektör Au cevherleşmesi: Bakırtepe Üyesine ait kuvarsitler içerisinde gelişmiş kırık ve çatlaklar içerisinde yer almaktadır. Kırıklar $\mathrm{K} 30^{\circ}-70^{\circ} \mathrm{D}$ doğrultulu olup $70^{\circ}$ $85^{\circ} \mathrm{GD}$ 'ya eğimli ya da dik olarak izlenmektedir (Şekil 2). Birbirlerine sub-paralel kırık hatlarının doğrultu boyunca uzanımları 350-2,000 m arasında değişmektedir. Au cevherleşmesi, ana ve tali kırık hatları içerisindeki kuvars, kuvars-hematit-limonit damar ve damarcıklarında izlenmektedir. Kuvars-hematit-limonit damarcıklarının kalınlıkları mm boyutundan 10 cm'ye kadar ulaşmaktadır. Kırık hatları boyunca cevherli zonların kalınlıkları ise 0.5-16 m arasında değişmektedir.

Bakırtepe güney sektör $\mathrm{Au}$ cevherleșmesi: DB ile $\mathrm{K} 70^{\circ} \mathrm{B} / 30-50^{\circ} \mathrm{KKD}$ konumlu tektonik hatlara paralellik sunan 3 farklı seviyede oluşmaktadır. Birinci seviye Kınalar Üyesi ile Düzce üyesi arasındaki tektonik hattın (bindirme fayı) tavan bloğundaki kireçtaşlarında izlenmekte olup $315 \mathrm{~m}$ uzanıma, 5-20 m arasında değişen kalınlığa sahiptir. İkinci ve üçünce seviyeler Düzce Üyesi içerisindeki kırıklara bağlı olarak gelişmiştir (Şekil 5). Ortada yer alan ikinci seviye $675 \mathrm{~m}$ uzanıma, 1.8-61.8 m arasında değişen kalınlığa sahiptir. En üstteki zon ise 672 m uzanıma, 5-35.5 m arasında değişen kalınlığa sahiptir. 


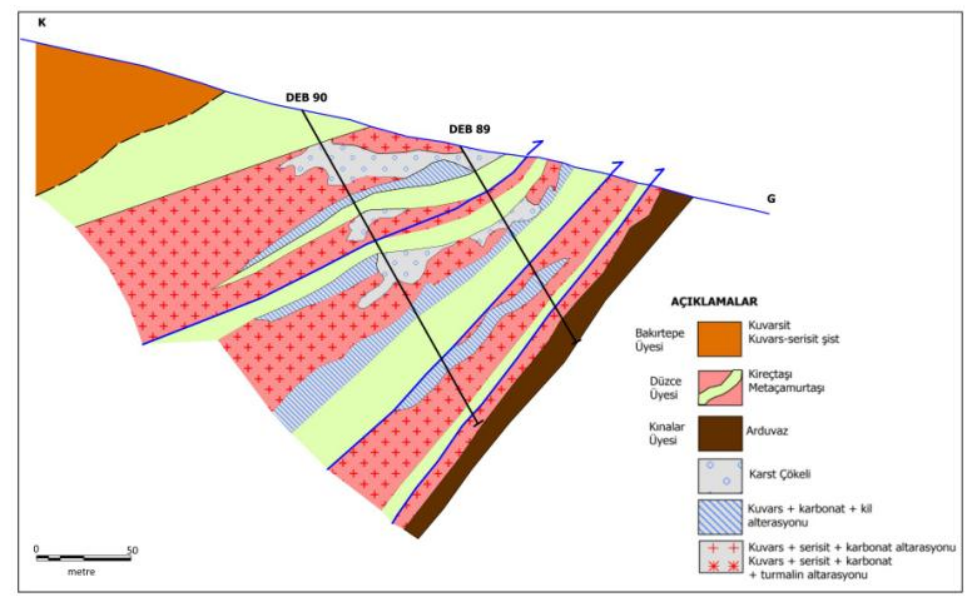

Şekil 5. Bakırtepe güney sektör altere zonları gösterir jeolojik kesit.

Figure 5. Geological section of Bakırtepe southern sector altered zones.

Tektonik hatlara paralellik sunan bu zonlarda, iki farklı aşamada gelişmiş alterasyon ve cevherleşmeye ait ürünler izlenmektedir. Birinci evrede kireçtaşları, kuvars-serizit, karbonat, hematit ve pirit tarafından ornatılmıştır. İkinci evrede ise silisleşme, killeşme, karbonatlaşma ve limonitleşme bir önceki evreye ait alterasyon ve cevherleşmeyi üzerlemiştir (Şekil 5). Bu 2 alterasyon aşaması sonrasında altere kireçtaşlarında gelişen karst çökelleri de Au içermektedir. Karst çökelleri farklı boyutlardaki altere ve cevherli dolomitik kireçtaşına ait parçalar ile az pekişmiş çamurtaşları ve limonitik matriksten oluşmaktadır. İnce ve kaba taneli malzemenin bir arada bulunması, çok evreli karstlaşma ve karst sedimantasyonunu işaret etmektedir. İnce detritiklerin ve/veya kimyasal çökelme ürünlerinin (limonit) hakim olduğu bölgelerde Au konsantrasyonunda artış gözlenmektedir. Ayrıca kaba detritiklerin hakim olduğu alanlardaki Au içeriği beslenen malzemenin türüne bağlı olarak değişim sunmaktadır. KG yönlü faylar boyunca kireçtaşında karstlaşmalar gelişirken diğer birimlerde ise sadece ezilme görülmektedir. Bu da karst geometrisinin birincil yapılarla uyumlu olmasını sağlamıştır (Şekil 5).

\section{Alterasyon}

Bakırtepe güney sektörde, alterasyon mineralojisine yönelik çalışmalar, karot, mostra ve işletme ocağından derlenen numunelerde yapılan ince kesit ve XRD sonuçları değerlendirilerek hazırlanmıştır. Bu çalışmalar sonucunda farkı iki aşamada gelişmiş alterasyon mineralleri belirlenmiştir. Illk aşamada gelişmiş olan kuvars- serizit - karbonat \pm turmalin alterasyonu (Şekil 6a) daha sonraki aşamada gelişmiş olan kuvars-karbonat-kil alterasyonu tarafından üzerlenmiştir (Şekil 6b). 


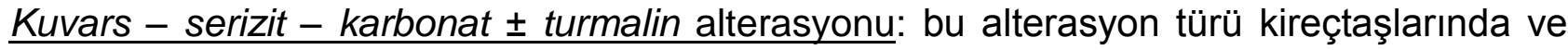
arduvazda izlenmektedir. Arduvazlarda yönlenme (dokusal özellikler) korunmasına rağmen yer yer kuvars dışındaki tüm minerallerin kuvars -serizit - turmalin - karbonattan (ankerit ve siderit) oluşan agregaya dönüştüğü gözlenmektedir. Turmalinler sadece arduvaz içerisinde kuvars ile birlikte izlenmektedir. Kireçtaşlarında ise saçınımlı ve damarcıklar şeklinde kuvars, serizit ve karbonat (ankerit ve siderit) alterasyonu gözlenmektedir. Ayrıca kireçtaşının bazı kesimlerinde bu alterasyon topluluğunda farklı yoğunlukta silisleşmeler baskındır. Ankerit ve sideritler kuvars ile birlikte damarcıklar şeklinde izlenmektedir.

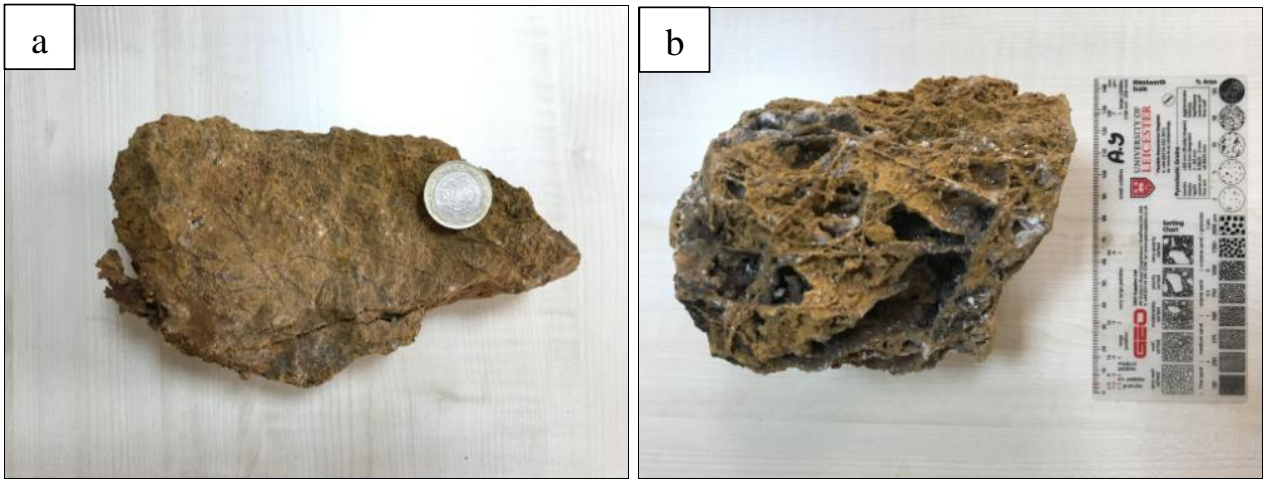

Şekil 6. Limonitleşmiş kuvars-serizit-karbonat (a) ve kuvars-karbonat-kil alterasyonlarına (b) ait el örnekleri.

Figure 6. Hand specimens of limonitized quartz-sericite-carbonate (a) and quartzcarbonate-clay (b) alterations.

Kuvars - karbonat - kil alterasyonu: bu alterasyon türü yaygın olarak kireçtaşında, kısmen ise arduvazlarda, sadece kırık-çatlak dolgusu şeklinde izlenmektedir.

Kireçtaşlarında bu evreye ait alterasyon ile bir önceki evrede oluşan serizitlerin kil minerallerine, pirit ve siderit/ankeritlerin ise kısmen limonite dönüştüğü belirlenmiştir. Alterasyon ürünü olarak kırık-çatlak dolgusu, karbonat+kuvars veya karbonat damarcıkları izlenmektedir. Ayrıca alterasyona breşleşme de eşlik etmektedir. Breş, kireçtaşı (0.5-10 $\mathrm{cm}$ ) parçaları ile kuvars, karbonat (kalsit ve ankerit) ve kil mineralleri içeren matriksten oluşmaktadır. Breşler, bazı bölgelerde tane destekli olarak görülmektedir. Hem parça hem de matriks içerisinde demir oksit ve mangan sıvamaları izlenmektedir. Bu alterasyon parajenezindeki kil minerallerine yönelik yapılan XRD çalışmaları sonucunda illit, simektit ve kaolinit belirlenmiştir. 
Bakırtepe güney sektör Au cevherleşmesinin bileşenlerinden biri olan karst çökellerinin matriksinde yapılan XRD çalışmalarında kalsit, opal-CT, götit ve kil grubu mineralleri belirlenmiştir.

\section{Cevher Mineralojisi}

Nabit altın, Kuzey sektörde kuvars-hematit-limonit damarcıklarının içerisinde kuvars veya hematit-limonit ile kenetli olarak bulunmaktadır. Tane boyu 2 mm'ye kadar ulaşmaktadır. Güney zondaki bütün alterasyonlarda ise kuvarsların aralarında, limonitleşmiş ankerit içinde veya limonit ile kenetli bulunan nabit altının tane boyutu ise 30-100 mikron arasında değişmektedir.

Pirit, güney sektörde kuvars-serizit-karbonat ve kuvars-karbonat-kil alterasyonuna uğramış arduvaz ve kireçtaşında saçınımlı ve damarcıklar şeklinde izlenmektedir. Bu zonlarda özşekilsiz olan piritler altere arduvazlar içerisinde korunmuş iken, kireçtaşında ise büyük bir bölümü limonite dönüşmüştür. Kuvars ve kalsit arasında yer yer korunmuş piritler gözlenir. Kuzey sektördeki tane boyutu 5 mm'ye kadar ulaşan özşekilli piritler ise psödomorflarını koruyarak tamamen hematite ve limonite dönüşmüş şekilde kuvarslar ile birlikte damar ve damarcıkların içerisinde yer almaktadır.

Hematit, Bakırtepe cevherleşmesinin tüm sektörlerinde saçınımlı, sıvama, damar ve damarcıklar şeklinde bulunmaktadır. Özşekilli ve yarı özşekilli taneler şeklinde izlenen hematit 45-600 mikron arası tane boyutuna sahiptir. Bakırtepe Kuzey zonda piritlerin dönüşüm ürünü ve sıvama şeklinde birincil olarak, Güney zondaki kuvars-serizit-karbonat (ankerit ve siderit) \pm turmalin alterasyonunda ve Naldöken sektöründe ise birincil olarak bulunmaktadır.

Mangan hidroksitler, ankeritin bozunma ürünü olarak çatlak ve boşluklarda amorf olarak bulunmaktadır.

Limonit, çatlak dolgusu, sıvama, saçınımlı ve damar (masif) şeklinde bulunmaktadır. Bakırtepe cevherleşmesindeki tüm sektörlerde pirit, hematit, ankerit ve sideritin bozunma ürünü olarak izlenmektedir. Ankeritler, kenar ve çatlakları boyunca özşekilsiz limonite, piritler ise psödomorflarını koruyarak limonite dönüşmüşlerdir. Güney sektörde kuvarskarbonat-kil alterasyonu içerisinde $10 \mathrm{~m}$ uzunluğa, $1 \mathrm{~m}$ kalınlığa kadar ulaşan amorf masif limonit oluşumları da gözlenmektedir. Ayrıca inceleme alanındaki tüm birimlerde yaygın olarak limonit sıvamaları izlenmektedir. Parlak kesit (iç yansıma renginin kahverengimsi 
kırmızı olması) ve XRD çalışmaları sonucunda limonitlerin büyük bir bölümünün götit olduğu belirlenmiştir.

Rutil, hidrotermal kuvars, pirit psödomorfları, limonit ve limonitleşmiş ankeritler içerisinde kapanım olarak bulunmaktadır. Rutil taneleri bazı kesimlerde bantlı yapıya uygun zenginleşmeler göstermektedir. $\mathrm{Bu}$ da kayacın mafik minerallerinin kuvars serizit alterasyonu sırasında rutile dönüştüğünü işaret etmektedir.

\section{Sıvı Kapanım Çalışmaları}

Sıvı kapanım çalışmaları sadece güney sektördeki altere zonlara yönelik olarak yapılmıştır. Alterasyonların birbirini üzerlemesi nedeniyle her alterasyona özgü numunede sıvı kapanım çalışması yapılamamıştır.

Sıvı kapanım çalışması yapılan 5 adet altere kayaç örneğinin mineralojik incelemelerinde yaşlıdan gence doğru kuvars, opak mineral ve kalsit belirlenmiştir. Sıvı kapanım çalışması kuvars damarcıklarında ve bunu kesen kalsit damarcıklarında yapılmıştır.

Sıvı kapanım çalışması yapılan kuvarslar yarı özşekilli olup en büyüğü 115 mikron tane boyutuna sahiptir. Kuvars içerisindeki sıvı kapanımlar yuvarlağımsı ve elipsoidal şekilde olup boyutları 2.5 ile 11 mikron arasındadır. 36 adet mikrotermometrik ölçüm yapılan kuvarslarda, birincil kökenli iki fazlı (sıvı+gaz) ve çok fazlı (sıvı+gaz+katı) kapanımlar belirlenmiştir. İki fazlı kapanımlarda homojenleşme sıcaklığının $470^{\circ} \mathrm{C}$ de başladığı, $230^{\circ}$ C'ye kadar devam ettiği görülmektedir (Şekil 7a). Çok fazlı kapanımlarda ise homojenleşme sıcaklığı $417^{\circ} \mathrm{C}$ ile $280^{\circ} \mathrm{C}$ arasında değişmekte olup (Şekil 7a) tuzluluk değerleri oldukça yüksektir (\% 34.1 ile \% 40.07 arasında). Homejenleşme sıcaklığındaki kümelenme ise $230^{\circ} \mathrm{C}$ ile $300^{\circ} \mathrm{C}$ arasındadır. Yapılan ölçümlerde aynı sıcaklıklarda sıvı ve gaz faza homojenleşmeler görülmektedir. Bu durum, ortamda kaynamanın olduğunu ve homejenleşme sıcaklığı ile oluşum sıcaklığının eşit olduğunu işaret edebilir (Roedder, 1984). Ayrıca $410-470^{\circ} \mathrm{C}$ homojenleşme sıcaklığına sahip sıvı kapanımlarının içerisinde opak mineral kapanımları (daughter mineral) belirlenmiştir. Bu durumda eriyik çözeltinin cevher taşıdığı söylenebilir.

21 adet mikrotermometrik ölçüm yapılan kalsitlerde, birincil kökenli iki fazlı (sıvı+gaz) ve tek fazlı (sıvı) kapanımlar belirlenmiştir. Sıvı kapanım çalışması yapılan kalsitler yarı özşekilli olup cm boyutuna ulaşmaktadır. Kalsit içerisindeki sıvı kapanımlar köşeli, üçgen ve düzensiz şekilde olup boyutları 5 ile 17 mikron arasındadır. İki fazlı kapanımlarda yapılan mikrotermometrik ölçümler sonucu elde edilen homojenleşme sıcaklığının $300^{\circ} \mathrm{C}$ 
ile $150^{\circ} \mathrm{C}$ arasında değiştiği görülmektedir (Şekil $7 \mathrm{~b}$ ). Belirlenen tuzluluk değerleri oldukça düşük olup \%1.6 ile \%3.1 arasında değişmektedir.
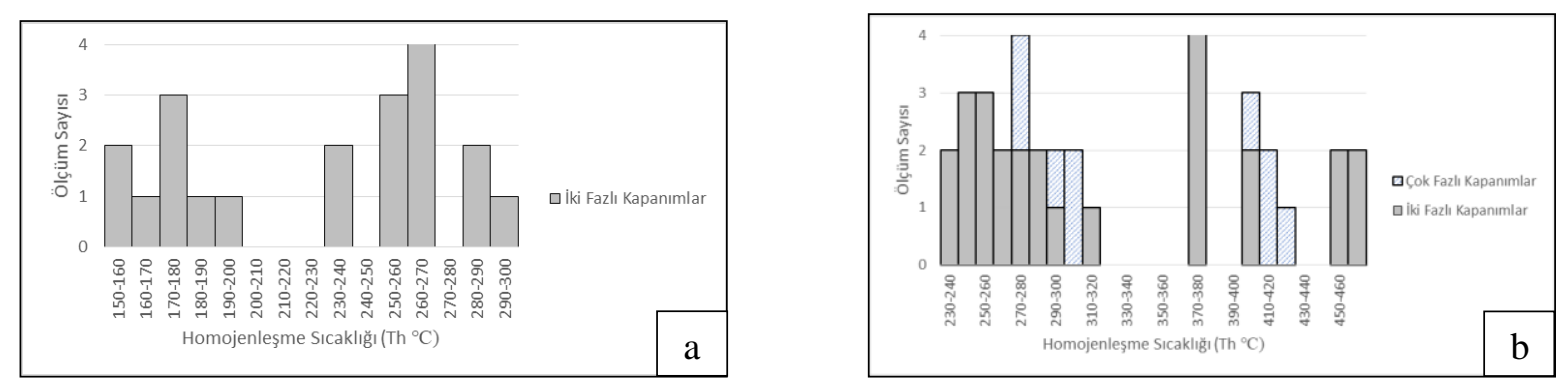

Şekil 7. (a) Kuvarslarda iki fazlı (sıvı+gaz) ve çok fazlı kapanımlarda yapılan homojenleşme sıcaklık değerleri dağılımı (kuvars-serizit-karbonat alterasyonuna ait). (b) Kalsitlerde iki fazlı (sıvı+gaz) kapanımlarda yapılan homojenleşme sıcaklık değerleri dağıımı (kuvars-karbonat-kil alterasyonuna ait).

Figure 7. (a) Distribution of homogenization temperature values of two-phased (liquid+gas) and multi-phased inclusions in quartz (quartz-sericite-carbonate alteration). (b) Distribution of homogenization temperature values of two phased (liquid+gas) inclusions in calcite (of quartzcarbonate-clay alteration).

Kuzey sektördeki kuvars damarlarında yapılan sıvı kapanım çalışmalarında ise homojenleşme sıcaklığının $250^{\circ} \mathrm{C}-390^{\circ} \mathrm{C}$ arasında değiştiği belirtilmiştir (Koçak ve Avcı, 2003).

\section{Jeokimya Çalışmaları}

Bakırtepe kuzey ve güney zondaki farklı alterasyonlardan alınan numenelere ait istatiksel bilgiler Çizelge 2'de verilmiştir. Jeokimya çalışmaları sonucunda, güney sektörde ilk evre alterasyondan son karstlaşma evresine doğru ilerledikçe Au konsantrasyonunun arttığı görülmektedir. Kuvars-serizit-karbonat alterasyonunda ve/veya kireçtaşlarında silis alterasyonunun baskın olduğu bölgelerde Au değerleri ortalama 53 ppb'dir. Kuvarskarbonat-kil alterasyonunun hakim olduğu bölgelerde ise ortalama Au değerleri 0.31 ppm'e ulaşmaktadır. İkincil karstlaşma ile birlikte ortalama Au değerleri 0.46 ppm'e yükselmektedir. Bu artış $\mathrm{Al}$, As, Ba, Ce, Co, Cu, Fe, K, Li, P, Pb, Sb, Ti, Ta, Th, Rb, Pb ve Zr gibi elementlerde de izlenmektedir. Ca ve Mg element konsantrasyonlarında ise, birincil evre alterasyondan son aşama karstlaşma sürecine doğru azalma izlenmektedir (Çizelge 2). Bakırtepe kuzey sektördeki Au değerleri ortalama 0.24 ppm olup bu zondaki diğer 
elementlerin içerikleri ise kuvars-serizit-karbonat ve kuvars-karbonat-kil alterasonuna benzerlik sunmaktadır (Şekil 8).

Çizelge 2. Bakırtepe altere zonların element içeriği (n:numune sayısı).

Table 2. Elemental content of Bakırtepe altered zones (n:number of samples).

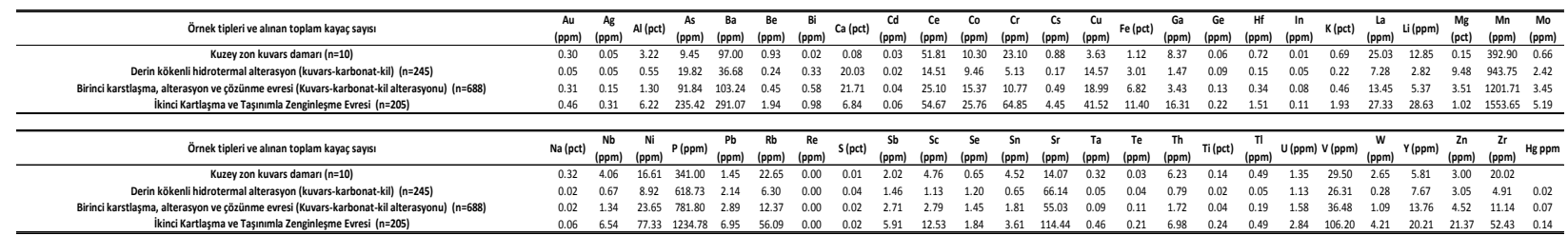

Altere ve cevherli zonlardaki Au içeriklerinin diğer elementlerle olan korelasyonunun çok zayıf veya zayıf olduğu görülmektedir. Kuvars-serizit-karbonat alterasyonunda $\mathrm{Au}, \mathrm{Fe}$ ve Te çok zayıf pozitif korelasyon sunmaktadır (Çizelge 3b). Kuvars-karbonat-kil alterasyonunda ise Au'nın her hangi bir element ile çok zayıf veya zayıf korelasyonu bulunmamaktadır (Çizelge 3c). İkincil karstlaşma süreçleri ile gelişen evrede ise Au'nun Bi, Co ve Fe elementleri ile zayıf pozitif korelasyon gösterdiği görülmektedir (Çizelge $3 d$ ). Kuzey sektörde ise Au sadece S elementi ile pozitif korelasyon sunmaktadır (Çizelge 3a). Bununla birlikte tüm alterasyon gruplarına ait baz ve değerli metalller ile hidrotermal süreçlerle ilgili bazı element dağılım desenleri birbirleriyle paralellik sunmaktadır.

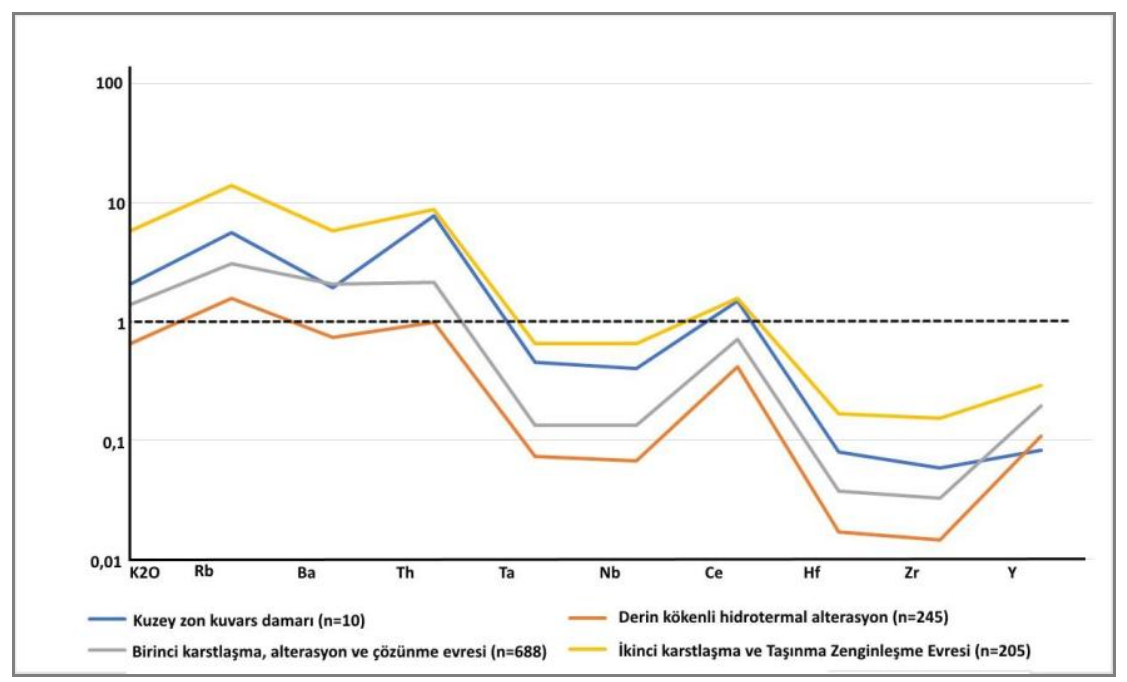

Şekil 8. Bakırtepe Mineralizasyon evrelerine ait Au ve hidrotermal süreçle ilişkili elementlerin dağılım desenleri.

Figure 8. Distribution patterns of elements related to Au and hydrothermal process belonging to Bakırtepe mineralization phases.

Üstte anlatılan jeokimyasal özellikler sonucunda Bakırtepe cevherleşmesinde ayırt edilen alterasyon ve karstlaşma süreçlerinin her birinin kendine özgü karakteristiklere sahip olduğu görülmektedir. Bunun yanı sıra hidrotermal süreçlerle ilgili elementlerin dağılım 
diyagramlarının birbirine parallellik sunması kuvars-serizit-karbonat alterasyonundan sonraki karstlaşma prosesleri ile yeni metal getirimlerinin olmadığı, sadece Au ve hidrotermal süreçlerle ilişkili elementlerde içerik artışı olduğu söylenebilir.

\section{CEVHERLEŞME VE ZENGINLEŞMENIN KAVRAMSAL MODELi̇}

Alterasyon, cevher mineralojisi ve sıvı kapanım çalışmaları karstlaşma süreçleriyle birlikte değerlendirilmiş olup Bakırtepe güney sektörü $\mathrm{Au}$ cevherleşme ve zenginleşme aşamalarını açıklamak üzere önerilen kavramsal model aşağıda verilmiştir. Önerilen kavramsal modele göre cevherleşme ve zenginleşme üç ana evrede gerçekleşmiştir: 1) derin kökenli hidrotermal evre ve Au cevherleşmesi, 2) birinci karstlaşma evresi ve çözünme sonucu zenginleşme ve 3) ikinci karstlaşma evresi ve taşınımla zenginleşme.

Çizelge 3. Bakırtepe altere zonlara [Kuzey zon kuvars damarı (a), Derin kökenli hidrotermal alterasyon (kuvars-serizit-karbonat) (b), Birinci karstlaşma, alterasyon ve çözünme evresi (kuvarskarbonat-kil alterasyonu) (c), İkinci karstlaşma ve taşınımla zenginleşme evresi (d)] ait orijinal verilerin korelasyon katsayıları.

Table 3. Correlation coefficients of original data [North zone quartz vein (a), deep-seated hydrothermal alteration (quartz-carbonate-clay) (b), primary karstification, alteration and dissolution phase (quartz, carbonate-clay) (c), secondary karstification and enrichment with transportation (d)].

\begin{tabular}{|c|c|c|c|c|c|c|c|c|c|c|c|c|}
\hline & $A u(p p m)$ & $A g(p p m)$ & As (ppm) & $B i(p p m)$ & $\mathrm{Cu}(p p m)$ & Co (ppm) & $\mathrm{Fe}(p c t)$ & $\mathrm{Pb}(p p m)$ & $S b(p p m)$ & $T I(p p m)$ & $Z n(p p m)$ & $S(p c t)$ \\
\hline $\mathrm{Au}(\mathrm{ppm})$ & 1 & & & & & & & & & & & \\
\hline $\mathrm{Ag}(\mathrm{ppm})$ & -0.15641 & 1 & & & & & & & & & & \\
\hline As (ppm) & -0.17051 & 0.219693 & 1 & & & & & & & & & \\
\hline $\mathrm{Bi}(\mathrm{ppm})$ & -0.15031 & -0.22847 & -0.0714 & 1 & & & & & & & & \\
\hline $\mathrm{Cu}(\mathrm{ppm})$ & -0.07915 & -0.25902 & 0.061174 & 0.977952 & 1 & & & & & & & \\
\hline Co (ppm) & -0.12827 & 0.008399 & 0.915059 & 0.301622 & 0.438758 & 1 & & & & & & \\
\hline $\mathrm{Fe}(\mathrm{pct})$ & -0.19756 & -0.09266 & 0.621801 & 0.707982 & 0.807308 & 0.86446 & 1 & & & & & \\
\hline $\mathrm{Pb}(\mathrm{ppm})$ & -0.13079 & -0.29216 & -0.04505 & 0.961457 & 0.974495 & 0.328802 & 0.7372 & 1 & & & & \\
\hline $\mathrm{Sb}(\mathrm{ppm})$ & -0.15738 & 0.562729 & 0.894614 & -0.08785 & 0.003831 & 0.768539 & 0.478737 & -0.10396 & 1 & & & \\
\hline $\mathrm{TI}$ (ppm) & -0.14241 & 0.124808 & 0.991279 & -0.10453 & 0.032354 & 0.910315 & 0.591519 & -0.08042 & 0.856898 & 1 & & \\
\hline $\mathrm{Zn}(\mathrm{ppm})$ & -0.01709 & 0.067596 & 0.656292 & 0.552126 & 0.657529 & 0.822041 & 0.919748 & 0.558944 & 0.513399 & 0.611213 & 1 & \\
\hline$S(p c t)$ & 0.66881 & -0.24279 & -0.24395 & -0.21951 & -0.16578 & -0.23514 & -0.21207 & -0.21186 & -0.42431 & -0.21666 & 0.063276 & 1 \\
\hline
\end{tabular}

\begin{tabular}{|c|c|c|c|c|c|c|c|c|c|c|c|c|c|}
\hline & $A u(p p m)$ & $A g(p p m)$ & As (ppm) & $B i(p p m)$ & $\mathrm{Cu}(p p m)$ & Co (ppm) & $\mathrm{Fe}(p c t)$ & $P b(p p m)$ & $S b(p p m)$ & $T I(p p m)$ & $Z n(p p m)$ & $\mathrm{Hg}(p p m)$ & $S(p c t)$ \\
\hline $\mathrm{Au}(\mathrm{ppm})$ & 1 & & & & & & & & & & & & \\
\hline $\mathrm{Ag}(\mathrm{ppm})$ & 0.131354 & 1 & & & & & & & & & & & \\
\hline As (ppm) & 0.051682 & 0.406826 & 1 & & & & & & & & & & \\
\hline $\mathrm{Bi}(\mathrm{ppm})$ & 0.038342 & 0.405029 & 0.320036 & 1 & & & & & & & & & \\
\hline $\mathrm{Cu}(\mathrm{ppm})$ & -0.02655 & 0.376095 & 0.212049 & 0.170405 & 1 & & & & & & & & \\
\hline Co (ppm) & 0.043898 & 0.183889 & 0.156526 & 0.618812 & 0.22822 & 1 & & & & & & & \\
\hline $\mathrm{Fe}(p c t)$ & 0.41915 & 0.228101 & 0.419219 & 0.399175 & 0.048822 & 0.412104 & 1 & & & & & & \\
\hline $\mathrm{Pb}(\mathrm{ppm})$ & -0.01562 & 0.093749 & 0.065415 & 0.105316 & 0.056718 & 0.13339 & 0.049107 & 1 & & & & & \\
\hline $\mathrm{Sb}(\mathrm{ppm})$ & -0.01363 & 0.701034 & 0.629081 & 0.399736 & 0.562665 & 0.224606 & 0.207415 & 0.081832 & 1 & & & & \\
\hline $\mathrm{TI}(\mathrm{ppm})$ & -0.03158 & 0.289462 & 0.352516 & 0.204276 & 0.119386 & 0.178098 & 0.15677 & 0.119574 & 0.31494 & 1 & & & \\
\hline Zn (ppm) & 0.014108 & 0.403757 & 0.289928 & 0.221428 & 0.243606 & 0.08131 & 0.170107 & 0.372618 & 0.450255 & 0.368672 & 1 & & \\
\hline
\end{tabular}




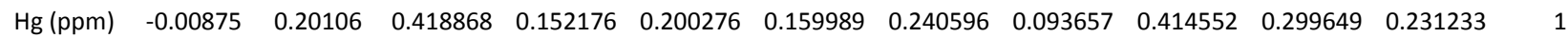

$\begin{array}{llllllllllllllll}\mathrm{S}(\mathrm{pct}) & -0.01456 & -0.00119 & -0.01216 & 0.119077 & 0.065771 & 0.284777 & 0.148915 & 0.006796 & 0.023252 & -0.00466 & -0.01905 & 0.025822 & 1\end{array}$

3(b)

\begin{tabular}{|c|c|c|c|c|c|c|c|c|c|c|c|c|c|}
\hline & $A u(p p m)$ & $A g(p p m)$ & As (ppm) & $B i(p p m)$ & $\mathrm{Cu}(\mathrm{ppm})$ & Co (ppm) & $\mathrm{Fe}(p c t)$ & $P b(p p m)$ & $S b(p p m)$ & $T I(p p m)$ & $Z n(p p m)$ & $\mathrm{Hg}(\mathrm{ppm})$ & $S(p c t)$ \\
\hline $\mathrm{Au}(\mathrm{ppm})$ & 1 & & & & & & & & & & & & \\
\hline $\mathrm{Ag}(\mathrm{ppm})$ & 0.053214 & 1 & & & & & & & & & & & \\
\hline As (ppm) & 0.100489 & 0.01004 & 1 & & & & & & & & & & \\
\hline $\mathrm{Bi}(\mathrm{ppm})$ & 0.177703 & 0.02869 & 0.412167 & 1 & & & & & & & & & \\
\hline $\mathrm{Cu}(\mathrm{ppm})$ & -0.01472 & 0.177661 & 0.127571 & 0.126308 & 1 & & & & & & & & \\
\hline Co (ppm) & 0.107227 & 0.01912 & 0.110878 & 0.172146 & 0.245588 & 1 & & & & & & & \\
\hline $\mathrm{Fe}(\mathrm{pct})$ & 0.259384 & 0.04348 & 0.358253 & 0.486179 & 0.031592 & 0.420127 & 1 & & & & & & \\
\hline $\mathrm{Pb}(\mathrm{ppm})$ & 0.015027 & 0.029813 & 0.087344 & 0.095183 & 0.1933 & 0.050363 & 0.077766 & 1 & & & & & \\
\hline $\mathrm{Sb}$ (ppm) & 0.008349 & 0.043939 & 0.218452 & 0.220463 & 0.462099 & 0.137893 & 0.156349 & 0.490681 & 1 & & & & \\
\hline TI (ppm) & -0.01073 & 0.004188 & 0.137591 & 0.032502 & 0.04847 & 0.290119 & 0.085637 & 0.021936 & 0.058869 & 1 & & & \\
\hline Zn (ppm) & -0.02788 & 0.054752 & 0.075182 & -0.0008 & 0.327053 & 0.068858 & 0.015537 & 0.384817 & 0.349792 & 0.099742 & 1 & & \\
\hline $\mathrm{Hg}(\mathrm{ppm})$ & 0.21668 & 0.090422 & 0.229542 & 0.130087 & 0.017172 & 0.161368 & 0.410534 & 0.14832 & 0.265128 & 0.147464 & 0.147729 & 1 & \\
\hline$S(p c t)$ & 0.002535 & -0.00256 & 0.003367 & 0.037925 & -0.0205 & 0.013862 & 0.035885 & 0.000193 & -0.00518 & -0.00843 & -0.02407 & -0.02004 & 1 \\
\hline
\end{tabular}

3(c)

\begin{tabular}{|c|c|c|c|c|c|c|c|c|c|c|c|c|c|}
\hline & $A u(p p m)$ & $A g(p p m)$ & As(ppm) & $B i(p p m)$ & $\mathrm{Cu}(p p m)$ & $\mathrm{Co}(p p m)$ & $\mathrm{Fe}(p c t)$ & $\mathrm{Pb}(p p m)$ & $S b(p p m)$ & $T e(p p m)$ & $Z n(p p m)$ & $\mathrm{Hg}(p p m)$ & $S(p c t)$ \\
\hline $\mathrm{Au}(\mathrm{ppm})$ & 1 & & & & & & & & & & & & \\
\hline $\mathrm{Ag}(\mathrm{ppm})$ & 0.130592 & 1 & & & & & & & & & & & \\
\hline $\mathrm{As}(\mathrm{ppm})$ & -0.01043 & -0.055 & 1 & & & & & & & & & & \\
\hline Bi (ppm) & 0.332709 & 0.526069 & 0.229436 & 1 & & & & & & & & & \\
\hline $\mathrm{Cu}(\mathrm{ppm})$ & -0.02227 & 0.047339 & 0.068611 & 0.034793 & 1 & & & & & & & & \\
\hline $\mathrm{Co}(\mathrm{ppm})$ & 0.581173 & 0.209284 & -0.03047 & 0.372187 & 0.154488 & 1 & & & & & & & \\
\hline $\mathrm{Fe}(\mathrm{pct})$ & 0.311374 & 0.275913 & 0.366502 & 0.636793 & 0.012901 & 0.451767 & 1 & & & & & & \\
\hline $\mathrm{Pb}(\mathrm{ppm})$ & 0.04411 & 0.069927 & 0.028818 & 0.191985 & 0.280266 & 0.239044 & 0.175179 & 1 & & & & & \\
\hline $\mathrm{Sb}$ (ppm) & 0.111263 & 0.134617 & 0.0158 & 0.237662 & 0.453952 & 0.323564 & 0.242419 & 0.46683 & 1 & & & & \\
\hline Te (ppm) & 0.235375 & 0.271886 & 0.055993 & 0.569197 & -0.11402 & 0.244973 & 0.574837 & 0.00403 & 0.044713 & 1 & & & \\
\hline Zn (ppm) & -0.1452 & -0.01952 & -0.1332 & -0.10113 & 0.274286 & 0.064611 & -0.107 & 0.56955 & 0.180738 & -0.15221 & 1 & & \\
\hline $\mathrm{Hg}(\mathrm{ppm})$ & -0.01224 & 0.026232 & -0.01024 & -0.00519 & -0.11345 & 0.291667 & 0.175402 & 0.138645 & 0.100099 & -0.0164 & -0.00729 & 1 & \\
\hline$S(p c t)$ & 0.272349 & 0.188835 & 0.295815 & 0.48055 & -0.07369 & 0.210812 & 0.634183 & -0.03253 & 0.041109 & 0.441233 & -0.18174 & -0.05285 & 1 \\
\hline
\end{tabular}

3(d)

\section{Derin kökenli hidrotermal evre ve Au cevherleşmesi}

Kınalar Üyesi üzerinde bindirme ile yer alan Düzce Üyesi'ne ait kireçtaşları ile kireçtaşının kendi içerisindeki D-B doğrultulu bindirme hatları boyunca hareket eden akışkanlar kireçtaşı ve arduvazlarda kuvars-serizit-karbonat (ankerit ve siderit) \pm turmalin alterasyonuna neden olmuştur. Bu alterasyon topluluğuna pirit ve hematit eşlik etmektedir. $\mathrm{Bu}$ zona ait kuvarslarda yapılan sıvı kapanım çalışmalarında elde edilen yüksek homojenleşme sıcaklığı $\left(470^{\circ} \mathrm{C}-250^{\circ} \mathrm{C}\right)$ ve tuzluluk değerleri (\%40-\%34) ile alterasyon mineral parajenezi (Corbett ve Leach, 1998) birlikte değerlendirildiğinde, ortamda jüvenil kökenli (derin kökenli) hidrotermal akışkanın dolaşım yaptığı söylenebilir. Aynı şekilde Bakırtepe kuzey sektöründeki kuvars-hematit-limonit damarcıklı zonun alterasyon parajenezi ile Koçak ve Avcı (2003) tarafından yapılan sıvı kapanım çalışmaları birlikte 
değerlendirildiğinde, derin kökenli alterasyon evresine ait olduğu söylenebilir. Bu akışkanların kökeni Pınargözü (Çetinkaya) Fe yatağında mostra veren granitik kayaçlar olabilir (Şekil 9).

\section{Birinci karstlaşma evresi ve çözünme sonucu zenginleşme}

Birinci karstlaşma evresi, D-B doğrultulu bindirme hatları boyunca derinden gelen çözücü jeotermal akışkanların yükselimi ile geliştiğinden, aşağıdan yukarı doğru ve farklı derinliklerde ve farklı hacimlerde boşluklar oluşturmuştur. Bu evrede kuvars-karbonat-kil alterasyonu gelişmiş olup derin kökenli kuvars-serizit-karbonat alterasyonunu üzerlemiştir. Ayrıca alterasyona breşleşme de eşlik etmektedir. Ortamdaki derin kökenli evrede gelişmiş piritin çözülmesi ile birlikte pH 4-5'e düşmüş olup (Corbett ve Leach, 1998) sistem asidik bir ortama geçmiştir. Bu durum kireçtaşında çözünme ve breşleşmelere neden olmuştur.

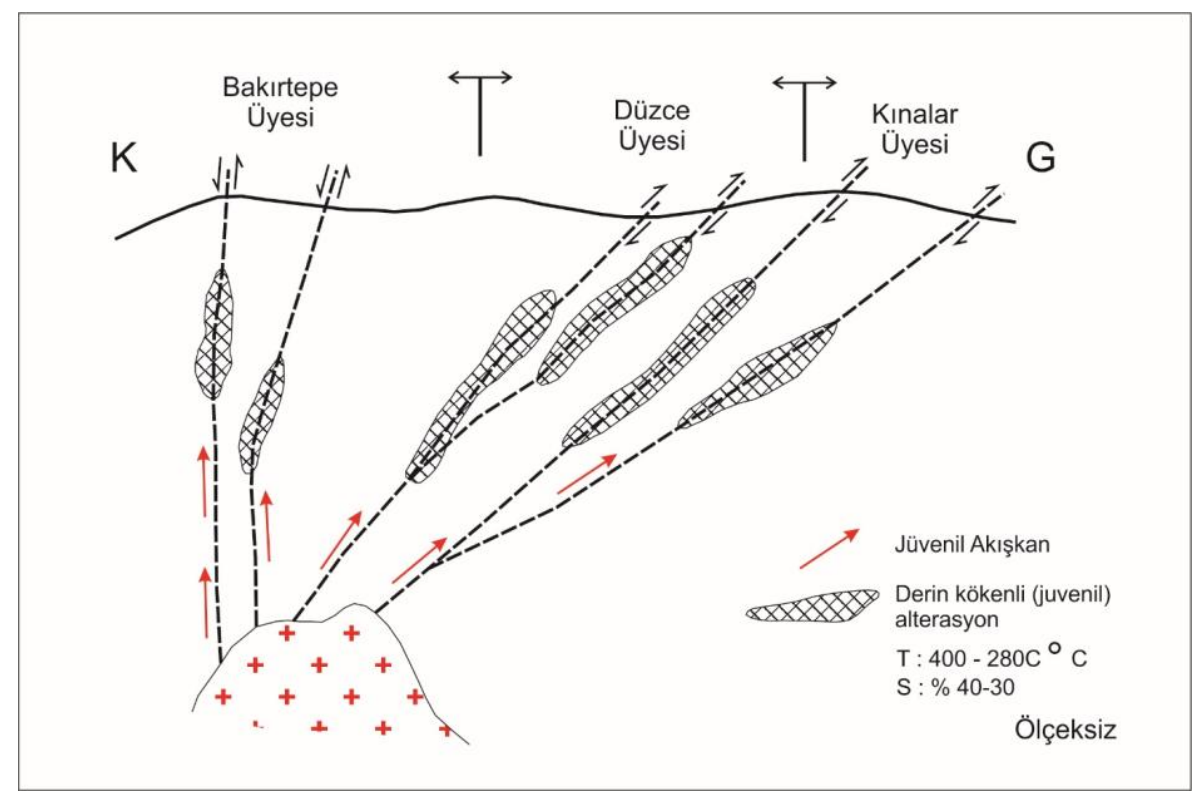

Şekil 9. Derin kökenli hidrotermal alterasyon ve Au cevherleşme evresi.

Figure 9. Deep-rooted hydrothermal alteration and phase of Au mineralization.

$\mathrm{Bu}$ zona ait kalsitlerde yapılan sıvı kapanım çalışmalarında elde edilen yüksek homojenleşme sıcaklığı $\left(300^{\circ} \mathrm{C}-150^{\circ} \mathrm{C}\right)$, tuzluluk değerleri $(\% 1.6$ - \%3.1) ve alterasyon mineral parajenezi (Corbett ve Leach, 1998) ile çözünme ve breşleşme süreçleri birlikte değerlendirildiğinde, birinci evreyi izleyen bu dönemde baskın olarak meteorik kökenli sulardan oluşan hidrotermal sistemin etkin olduğu söylenebilir. Birinci evrede hakim olan jüvenil suların katkısının kalmadığı veya çok düşük düzeyde olduğu anlaşılmaktadır. Kırık zonlarında dolaşan bu hidrotermal akışkanın sistem üzerinde iki etkisi olmuştur: a) Sistemde ikinci bir alterasyon süreci başlatarak, birinci evrede oluşan alterasyonun, 
kuvars-karbonat-kil alterasyonu tarafından üzerlemesine neden olmuştur (Şekil 10), b) Karbonatlı (kireçtaşı) seviyelerde çözünmeye yol açarak karstlaşma süreçlerini başlatmıştır. İnce kesit ve XRD çalışmaları, bu evreye ait alterasyon süreçleri sonucunda kuvars, illit, simektit, kaolinit ve karbonat (kalsit-ankerit) minerallerinin varlığını ortaya koymuştur. Karstlaşma sonucunda bir önceki evreye ait karbonat minerallerinin (kalsit, ankerit ve siderit) çözünmesi ile katı fazdaki çözünebilir minerallerin bileşenleri iyonlar halinde $\left(\mathrm{Ca}^{+2}\right.$ ve $\left.\mathrm{HCO}_{3}{ }^{-}\right)$akışkana (sıvı fazda) geçerek ortamdan uzaklaşmış, bu şekilde cevher minerallerinin derişimi (birim hacimdeki cevher miktarı) göreli olarak artmıştır. Karstlaşma sonucunda ortamdan uzaklaşan çözünebilir minerallerden arta kalan silis içerikli mineraller (killer) ile birlikte cevher mineralleri bu süreçte gelişen karstik boşluklarda çökelmişlerdir.

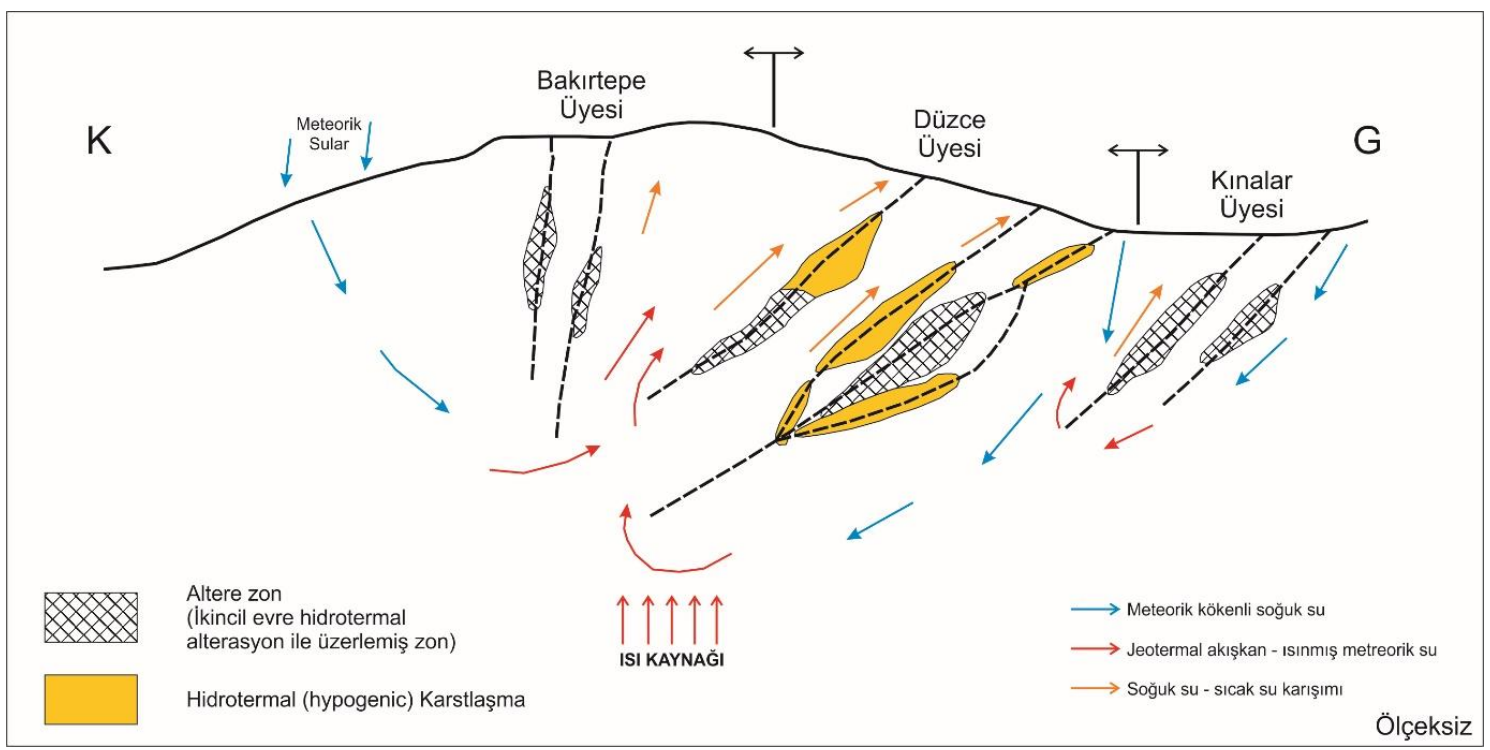

Şekil 10. Birinci karstlaşma, alterasyon ve çözünme sonucu zenginleşme evresi.

Figure 10. Enrichment phase resulted from first karstification, alteration and dissolution.

$\mathrm{Bu}$ evrede çözünebilir mineraller ortamdan uzaklaşmış ve cevher mineralleri ortamda göreceli olarak zenginleşmiştir.

\section{İkinci karstlaşma evresi ve taşınımla zenginleşme}

Bölgesel tektonizma sonucu K-G doğrultulu yeni fay ve kırık hatlarının gelişmesi sonucunda, yüzey sularının bu hatlarda yeni bir karstlaşma evresi oluşturduğu anlaşılmaktadır. K-G doğrultulu fay zonlarında, Türkiye'nin karst kuşaklarında gözlenen karst tipine (Ekmekçi, 2003) uygun yapılar belirlenmiştir. 
K-G doğrultulu daha genç fayların gelişmesiyle etkinleşmiş ikinci evre karstlaşmalar, daha çok soğuk meteorik suların yüzeyden derinlere doğru süzülürken rekristalize kireçtaşlarını çözmesi sonucunda oluşmuştur. Bu evrede karstlaşma daha çok K-G doğrultulu fay zonları boyunca etkili olmuştur (Şekil 11).

Yüzeyden derine doğru gelişen bu karstlaşma evresinde, karstik alanlara özgü hidrolojik süreçler hakim olmuş, yüzeysel akışa geçen yağış suları düden gibi karstik yapılar kanalıyla hızı bir şekilde yeraltına iletilmiştir. Ortamdaki pirit oluşumlarının

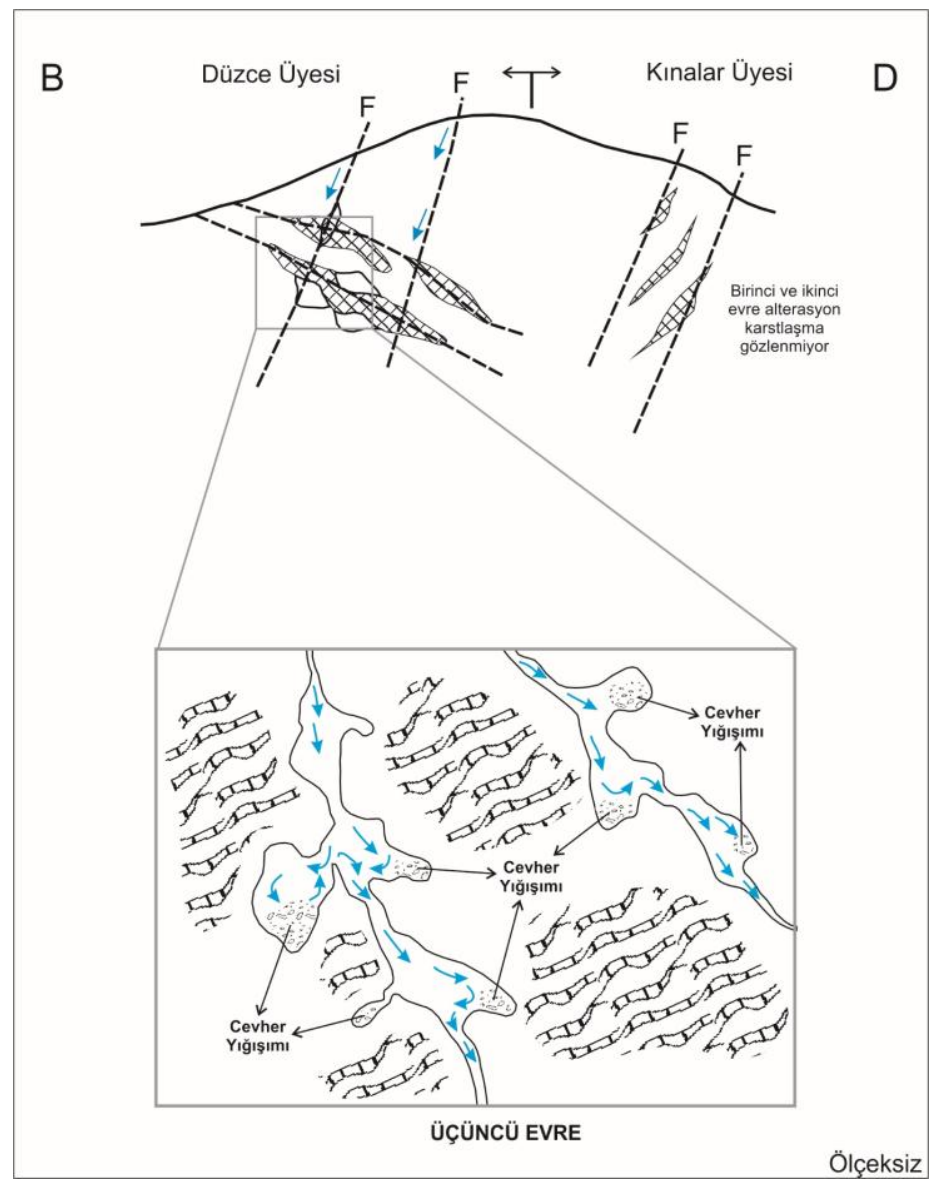

Şekil 11. İkinci karstlaşma ve taşınımla zenginleşme evresi.

Figure 11. Enrichment phase with second karstification and transportation.

yükseltgenmesi sonucunda meteorik suların asitliği, dolayısıyla çözücülüğü artmış olmalıdır.

Yeraltına hızla iletilen yüzeysel akış, bir önceki evrede zenginleşen minerallerin fiziksel olarak akışla taşınmasını sağlamıştır. Su ile taşınan parçalar (Au içeren hematitli, limonitli ve silisli zonlar) daha derinlerde cepler oluşturan karstik boşluklarda yığışarak depolanmışlardır (Bkz. Şekil 11). Karst çökelleri içerisinde, düşük ısılı mineraller (zeolit, simektit) gözlenmektedir. 
Bu karstik boşlukların “ölü cepleri” olarak tanımlanabilecek kesimleri Au zenginleşmelerinin rastlandığı lokasyonları oluşturmuşlardır (Bkz. Şekil 11, ayrıntı). Bu süreçlerin sonucu olarak cevherli zonlara ait parçaların dağılımı belli bir düzen içinde izlenememektedir.

İlk gözlemlere göre karstik boşluklarda biriken kil minerallerinin yoğunlaştığı kesimlerde cevher oluşumlarının birlikteliği beklenebilmekte, ancak her kil dolgusu bulunduran karstik boşlukta altın zenginleşmesine rastlanılmamaktadır (Şekil 12a). Kayaç içinde gelişmiş ve su akışına olanak verecek şekilde birbirleriyle bağlantılı karstik boşluklarda cevher mineralleri de akışla birlikte taşınmış ve "cep" oluşturan karstik boşluklara ulaşıldığında burada önceki evrelere ait cevher parçalarının çökeldiği anlaşılmaktadır (Şekil 12b). Bu örüntü sonucunda, zenginleşmiş cevher oluşumları, karstik ceplerin dağılımına benzer bir şekilde ve bu ceplere bağlı olarak düzensiz bir dağılım göstermektedir. İşletme açısından büyük önem taşıyan bu durumun açıklanabilmesi karstlaşma evriminin ortaya konmasını gerektirmiştir.
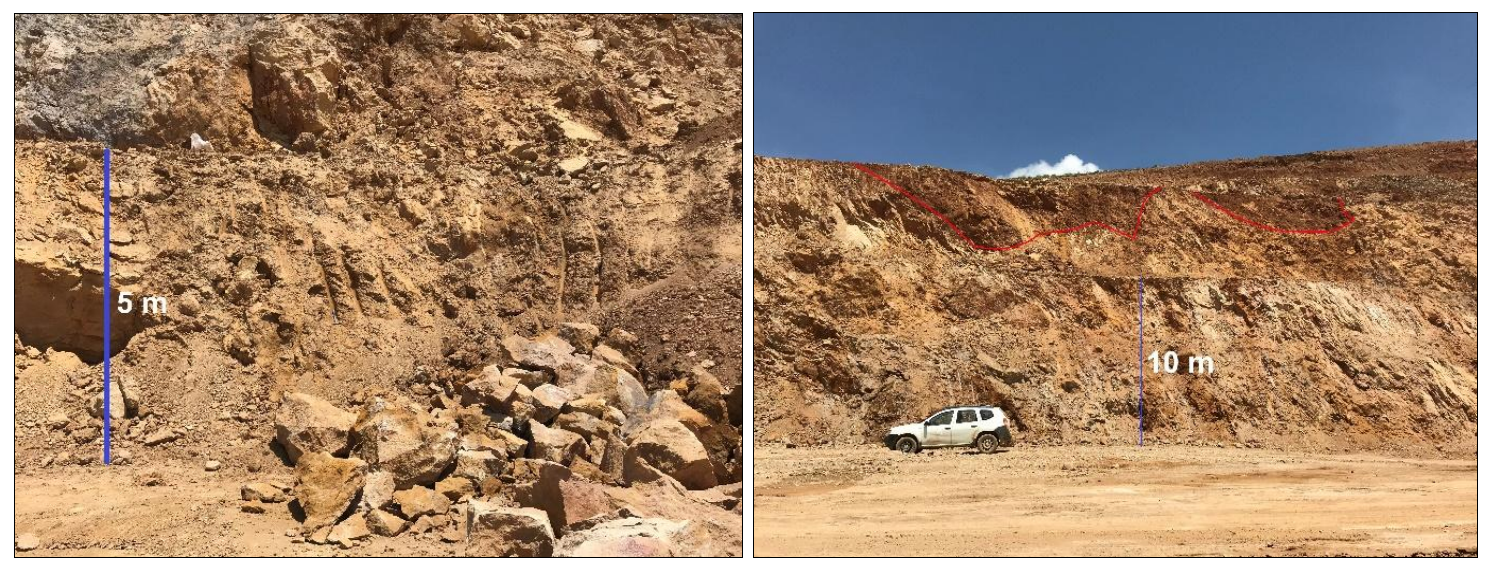

(a)

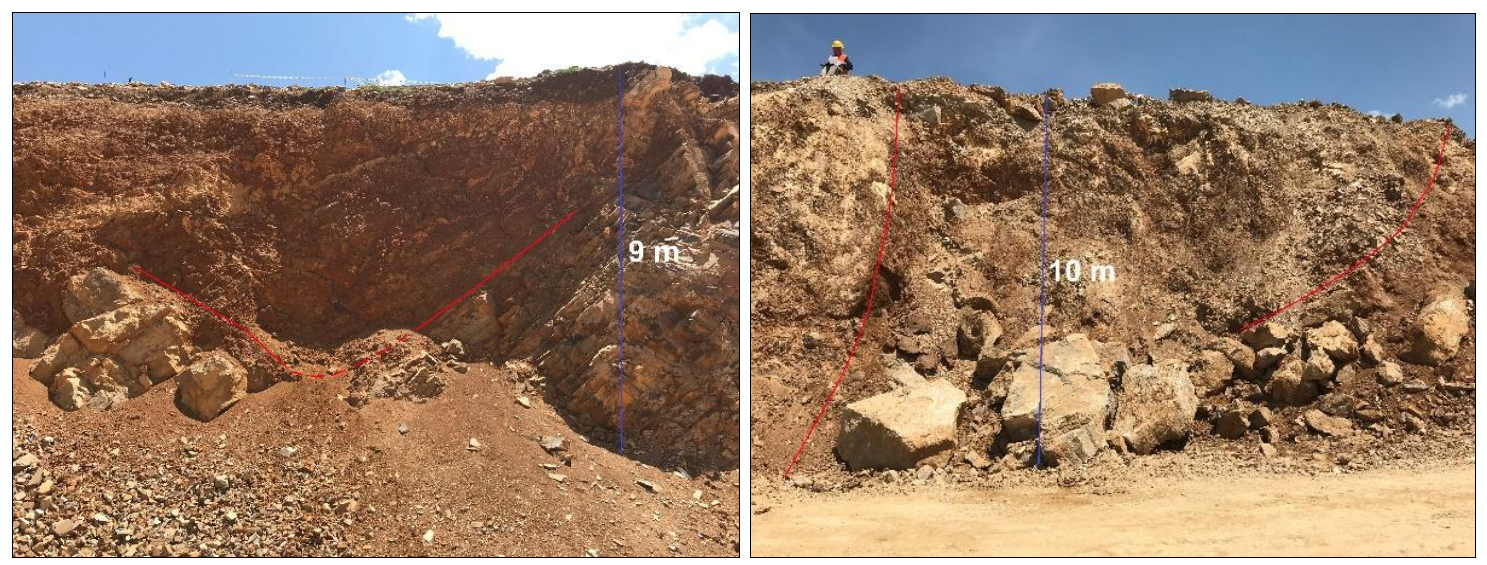

(b)

Şekil 12. Ocak içerisindeki (a) cevhersiz ve (b) cevherli karstik boşluklar.

Figure 12. a) Ore-bearing and b) non ore-bearing karstic cavities in the pit area. 


\section{SONUÇLAR}

Bakırtepe ve yakın çevresinde Erken Paleozoyik-Mesozoyik yaşlı Toros Göreli Otoktonuna ait kırıntılı ve karbonatlı kayaçlar içerisinde 3 farklı lokasyonda Au mineralizasyonu izlenmektedir. Bu çalışma kapsamında Bakırtepe güney sektör cevherleşmesinin oluşum ve zenginleşme evreleri irdelenmiştir.

Yapılan çalışmalardan elde edilen veriler ışığında, Bakırtepe güney sektöründe genel olarak cevherleşmenin ve zenginleşmenin, birbirlerinden ayrılabilen üç farklı evrede gerçekleştiği ortaya konmuştur. Yapılan değerlendirmeler, cevherleşme süreçlerini denetleyen hidrotermal alterasyonun iki evre halinde gerçekleşmiş olduğunu göstermektedir. Birinci evre, derin kökenli akışkan getirimi ile temsil edilmekte olup Kangal Formasyonunun tüm üyelerini (Kınalar, Düzce ve Bakırtepe) aynı şekilde etkilemiştir.

Meteorik kökenli suların derinlere doğru süzülerek oluşturduğu hidrotermal sistemin neden olduğu ikinci hidrotermal evre benzer şekilde her üç üyeyi de etkilemiş, ancak karbonatlı seviye içeren Düzce Üyesinde ayrıca karstlaşmaya neden olmuştur. Hidrotermal alterasyon sonucu meydana gelen cevherleşmenin ardından ikinci evrede cevherli zonların ikinci evre hidrotermal getirimle hipojenik karstlaşma sonucunda zenginleşmesine karşılık gelmektedir. Düzce Üyesinde etkili olan karstlaşma, karbonat minerallerinin çözünerek ortamdan uzaklaşması ile aynı zamanda belirli oranda cevher zenginleşmesini de sağlamıştır. Bu evredeki karstlaşma hipojenik karstlaşma niteliğindedir.

Üçüncü evre, Düzce üyesinin kireçtaşı seviyelerinde ve cevherli zonlarda meteorik kökenli soğuk suların etkisiyle gerçekleşen normal karstlaşmaya bağlı olarakgözlenmektedir. Karstlaşma bu evrede, hipojenik karstlaşmadan farklı olarak, meteorik suların neden olduğu normal karstlaşma niteliğindedir. Karstlaşma sonucu yüzey sularının yeraltı karst boşluklarındaki hızlı hareketi ile ikinci evrede zenginleşmiş cevher oluşumları taşınarak "cep” olarak tanımlanan karstik boşluklarda yığışmışlardır. Bu tür ceplerin dağılımı ve boyutları tamamen gelişigüzel ve düzensizdir. Yüksek Au değerleri içeren cevher oluşumlarına bu tür ceplerde rastlanılırken, akışa izin veren karstik boşluklar cevher içermeyebilmektedir. Yığışımla Au zenginleşmesi gözlenen karstik ceplerin haritalanması sonucunda işletme sırasında cevherin devamlılığı konusunda yaşanan sorunlar büyük ölçüde çözülmüştür. 


\section{KATKI BELIRTME}

Yazarlar bu çalışmanın yapılması sırasında göstermiş olduğu destekten dolayı Demir Export A.Ş. Genel Müdürü Sayın Ramazan Yön'e ve yapıcı eleştiri ve katkıları nedeniyle hakemlere teşekkür ederler.

\section{KAYNAKLAR}

Annels, A. E., 1991. Mineral Deposits Evaluation. A Practical Approach. Chapman and Hall, London, New York.

Bayhan, H., 1980. Güneş-Soğucak (Divriği/Sivas) yöresinin jeolojik, mineralojik, petrografik, petrolojik ve metalojenik incelemesi. Doktora Tezi, Hacettepe Üniversitesi, Ankara (yayımlanmamış).

Beyazpirinç, M., Akçay, A. E., Metin, Y., Taptık, M. A., Öcal, H., Çobankaya, M., Çoban, M., Doğan, A., Bağcı, U., Rızaoğlu, T., 2010. Doğu Toroslar'ın jeodinamik evrimi (Sivas-Malatya-Kahramanmaraş-Kayseri) 2008 yılı arazi raporu. Maden Tetkik ve Arama Genel Müdürlüğü, Rapor No: 11331, Ankara (yayımlanmamış).

Beyazpirinç, M., Akçay, A.E., 2013. Alacahan-Çetinkaya (Kangal-Sivas) yöresindeki metamorfitlerin tektono-stratigrafik özellikleri. MTA Dergisi, 147, 19-29.

Boztuğ, D., Debon, F., İnan, S., Tutkun, S.Z., Avcı, N.,Kesgin, Ö., 1997. Comparative geochemistry of four plutons from the Cretaceous-Paleogene Central Eastern Anatolian alkaline province (Divriği Region, Sivas, Turkey). Turkish Journal of Earth Sciences, 6, 95-115.

Corbett, G. J., Leach, T. M., 1998. Southwest Pacific rim gold-copper systems: structure, alteration, and mineralisation. Society of Economic Geologists Special Publication 6, p.234. 
Demir Export, 2008. Sivas-Kangal-Çetinkaya-Bakırtepe altın sahası jeoloji raporu, Ankara.

Dominy, S.C., Noppe, M. A., Annels, A.E., 2002. Errors and uncertainty in mineral resource and ore reserve estimation: The importance of getting it right. Explor. Mining Geology, $11(1-4), 77-98$.

Ekmekçi, M., 2003. Review of Turkish karst with emphasis on tectonic and paleogeographic controls, Acta Carsologica, vol. 31(3).

Gawlik, J., 1961. Pınargözü-Davutoğlu Hematit Yatağındaki Çalışma Programı. Maden Tetkik ve Arama Genel Müdürlüğü, Rapor No: 2809, Ankara.

Goldsmith, T., 2002. Resource and Reserves - Their impact on financial reporting, valuations and the expectations gap. Proceedings of the CMMI Congress: International codes, technology and sustainability for the minerals industry: 2002. Australasian Institute of Mining and Metallurgy, AuSIMM, Carlton South.

Gültekin, A.S., 1993. Alacahan-Çetinkaya-Divriği (Sivas) arasında kalan alanın jeolojisi. Doktora tezi, İstanbul Üniversitesi, 180 s, İstanbul (yayımlanmamış).

Gümüş, A., 1963. Pınargözü-Davutoğlu (Sivas Çetinkaya) hematit yatağı hakkında nihai jeolojik rapor. Maden Tetkik ve Arama Genel Müdürlüğü, Rapor No:3281, Ankara (yayımlanmamış).

Karakaya, A.O., 2011. Sivas-Kangal-Çetinkaya-Pınargözü Demir Yatağının Jeolojik ve Jeokimyasal Özellikleri. Yüksek Lisans tezi, Hacettepe Üniversitesi, Ankara.

Koçak, A., Avcı, N., 2003. Bakırtepe-Çetinkaya-Kangal-Sivas altın aramaları ön etüt raporu. Maden Tetkik ve Arama Genel Müdürlüğü, Rapor No:10620, Ankara (yayımlanmamış). 
Özgül, N., 1976. Torosların bazı temel jeoloji özellikleri. Türkiye Jeoloji Kurumu Bülteni, 19(1), 65-78.

Özgül, N., Turşucu, A., Özyardımcı, N., Şenol, M., Bingöl, İ., Uysal, Ş., 1981. Munzur Dağlarının jeolojisi. Maden Tetkik ve Arama Genel Müdürlüğü, Rapor No:6995, Ankara (yayımlanmamış).

Revan, M. K., Genç, Y., 2003, Malatya-Yeşilyurt Altınlı Florit Cevherleşmesi: Toroslarda Paleokarst Tipi Bir Yatak. Jeoloji Mühendisliği Dergisi, 27(2), 76-93.

Revan, M. K., Genç, Y., Dumanlılar, Ö., 2003, Malatya-Yeşilyurt: Altınlı Florit Cevherleşmeleri, 56. Türkiye Jeoloji Kurultayı Bildiri Özleri, s. 118.

Roedder, E., 1984, Fluid inclusions, Min. Soc. Am. Rev. in Min., v.12, 646p.

Sayar, C., Gültekin, A.S., 1993. Kangal (Sivas) çevresi yeşilşist fasiyesinde DevoniyenKarbonifer Brakiyopodları. 46. Türkiye Jeoloji Kurultayı Bild,,iri Özleri, s.136.

Stephenson, P.R., Vann, J., 2001. Common sense and good communication in mineral resource and ore reserve estimation. In Mineral Resource and Ore Reserve Estimation - The AusIMM Guide to Good Practice. The Australasian Institute of Mining and Metallurgy: Melbourne, 13-20.

Stone, J.G., Dunn, P.G., 1996. Ore Reserve Estimates in the Real World. Society of Economic Geologists Special Publication, Littleton.

Şengör, A.M.C., Yılmaz, Y., 1981. Tethyan evolution of Turkey; a plate tectonic approach. Tectonophysics, 75, 181-241. 
Tekin, Z., Keskin, Ö., Ak, S., Koçak, A., Avcı, N., 1993. Sivas-Divriği-Kangal Alacahan Yöresinin Jeokimyasal Prospeksiyon Raporu. Maden Tetkik ve Arama Genel Müdürlüğü, Rapor No: 9915, Ankara.

Uçurum, A., Usman, A., Lechler, P.J., Arehart G.B., Molnar, F., 2007. Geology, Geochemistry, Stable Isotope, and Fluid Inclusion Investigation of the Iron OxideGold Mineralization in Bakirtepe, Kangal-Sivas, East-Central Turkey, International Geology Review, 49(8), 753-767, doi: 10.2747/0020-6814.49.8.753.

Yalçın, H., Bozkaya, Ö., 1997. Kangal-Alacahan yöresi (Sivas) Üst Paleozoyik yaşlı metasedimanter kayaçlarda gömülme ve bindirme ile ilişkili çok düşük dereceli metamorfizma. Türkiye Jeoloji Bülteni, 40(2), 1-16.

Yılmaz, H., Yılmaz, A., 2004. Divriği (Sivas) yöresinin jeolojisi ve yapısal evrimi. Türkiye Jeoloji Bülteni, 47,13-45. 